\title{
Spectrally resolved efficiencies of carbon monoxide (CO) photoproduction in the western Canadian Arctic: particles versus solutes
}

\author{
G. Song ${ }^{1}$, H. Xie ${ }^{1}$, S. Bélanger ${ }^{2}$, E. Leymarie ${ }^{3}$, and M. Babin ${ }^{4}$ \\ ${ }^{1}$ Institut des sciences de la mer de Rimouski, Université du Québec à Rimouski, Rimouski, Québec, G5L 3A1, Canada \\ ${ }^{2}$ Département de biologie, chimie et géographie and BORÉAS, Université du Québec à Rimouski, Rimouski, Québec, \\ G5L 3A1 Canada \\ ${ }^{3}$ Université Pierre et Marie Curie, Laboratoire d'Océanographie de Villefranche, Centre National de la Recherche \\ Scientifique, Villefranche-sur-Mer, France \\ ${ }^{4}$ Takuvik Joint International Laboratory (CNRS \& ULaval), Département de Biologie, Québec-Océan and Arcticnet, \\ Université Laval, Québec, Québec, G1V 0A6, Canada
}

Correspondence to: H. Xie (huixiang_xie@uqar.qc.ca)

Received: 17 September 2012 - Published in Biogeosciences Discuss.: 15 November 2012

Revised: 4 March 2013 - Accepted: 6 May 2013 - Published: 5 June 2013

\begin{abstract}
Spectrally resolved efficiency (i.e. apparent quantum yield, AQY) of carbon monoxide (CO) photoproduction is a useful indicator of substrate photoreactivity and a crucial parameter for modeling $\mathrm{CO}$ photoproduction rates in the water column. Recent evidence has suggested that $\mathrm{CO}$ photoproduction from particles in marine waters is significant compared to the well-known CO production from chromophoric dissolved organic matter (CDOM) photodegradation. Although CDOM-based CO AQY spectra have been extensively determined, little is known of this information on the particulate phase. Using water samples collected from the Mackenzie estuary, shelf, and Canada Basin in the southeastern Beaufort Sea, the present study for the first time quantified the AQY spectra of particle-based CO photoproduction and compared them with the concomitantly determined CDOM-based CO AQY spectra. CO AQYs of both particles and CDOM decreased with wavelength but the spectral shape of the particulate AQY was flatter in the visible regime. This feature resulted in a disproportionally higher visible lightdriven $\mathrm{CO}$ production by particles, thereby increasing the ratio of particle- to CDOM-based $\mathrm{CO}$ photoproduction with depth in the euphotic zone. In terms of depth-integrated production in the euphotic zone, CO formation from CDOM was dominated by the ultraviolet (UV, 290-400 nm) radiation whereas UV and visible light played roughly equal roles
\end{abstract}

in $\mathrm{CO}$ production from particles. Spatially, CO AQY of bulk particulate matter (i.e. the sum of organics and inorganics) augmented from the estuary and shelf to the basin while CO AQY of CDOM trended inversely. Water from the deep chlorophyll maximum layer revealed higher CO AQYs than did surface water for both particles and CDOM. CO AQY of bulk particulate matter exceeded that of CDOM on the shelf and in the basin, but the sequence reversed in the estuary. Without consideration of the potential role of metal oxides (e.g. iron oxides) in particle photochemistry, mineral absorption-corrected CO AQY of particulate organic matter (POM) could, however, surpass its CDOM counterpart in all three sub-regions and displayed magnitudes in the estuary that overtook those in shelf and offshore waters. In terms of $\mathrm{CO}$ photoproduction, $\mathrm{POM}$ was thus more photoreactive than CDOM, irrespective of the organic matter's origins (i.e. terrigenous or marine). Riverine CDOM exhibited higher photoreactivity than marine CDOM and land-derived POM appeared more photoreactive than marine POM. AQY-based modeling indicates that $\mathrm{CO}$ photoproduction in the study area is underestimated by $12-32 \%$ if the particulate term is ignored. 


\section{Introduction}

The absorption of solar ultra-violet (UV) and visible radiation by chromophoric dissolved organic matter (CDOM) initiates a myriad of chemical reactions that significantly impact marine biogeochemical cycles. CDOM photooxidation plays a critical role in controlling the transformation and fate of dissolved organic carbon (DOC) by mineralizing DOC to carbon dioxide $\left(\mathrm{CO}_{2}\right)$ and carbon monoxide (CO) (Miller and Zepp, 1995) and by altering the microbial degradability of DOC (Benner and Biddanda, 1998). CDOM photoprocesses also produce labile nitrogen (Bushaw et al., 1996) and oxidize dimethyl sulfide (Brimblecombe, 2003), thereby influencing marine nitrogen and sulfur cycling in the ocean. While colossal efforts and progress have been made in CDOM photochemistry during the last several decades (see reviews by Mopper and Kieber, 2002; Zafiriou, 2002; Zepp, 2003), much less attention has been paid to photochemical processes involving particulate organic matter (POM). The similarity in the absorption spectrum between POM and CDOM (Kirk, 1980), however, implies that POM may undergo photochemical transformations analogous to those of CDOM. Besides, POM photochemistry could be more efficient due to enrichment of organic substrates and/or photoreactive metals (e.g. $\mathrm{Fe}, \mathrm{Cu}, \mathrm{Mn}$ ) in localized microenvironments on or within particles (Zafiriou, 2002), as suggested by studies on photodegradation of chlorophylls and unsaturated lipids of phytoplankton (e.g. SooHoo and Kiefer, 1982; Nelson, 1993; Rontani, 2001). Early surveys have demonstrated that irradiation of detritus of certain vascular plants produces $\mathrm{CO}$ (Tarr et al., 1995) and $\mathrm{CO}_{2}$ (Anesio et al., 1999a) and releases DOC (Anesio et al., 1999b). More recently, a few groups have reported significant losses of particulate organic carbon (POC) and productions of DOC, $\mathrm{CO}_{2}, \mathrm{DON}$, and CDOM from controlled irradiation of resuspensions of river and coastal sediments (Kieber et al., 2006; Mayer et al., 2006; Riggsbee et al., 2008; Pisani et al., 2011; Shank et al., 2011). Similar results have been found for phytoplankton detritus, with an added finding of ammonium production (Mayer et al., 2009; Estapa and Mayer, 2010).

Although laboratory irradiation experiments suggest potentially significant biogeochemical cycling rates resulting from POM photodegradation, extrapolating these results to real environments often entails potentially large uncertainties due partly to limited sample coverage and the inability of controlled incubations to adequately simulate the more complex optical, chemical, and hydrological conditions occurring in natural waters (Mayer et al., 2009; Estapa and Mayer, 2010). A widely adopted approach for estimating CDOM photochemical fluxes is coupled optical-photochemical modeling based on measured efficiency spectra of the photoprocess in question (e.g. Zafiriou et al., 2003; Xie et al., 2009; Fichot and Miller, 2010), which in principle can also be applied to POM photochemistry. However, efficiency (also termed apparent quantum yield, AQY) spectra of POM photore- actions have rarely been determined. Estapa et al. (2012a) reported the AQY spectra of DOC photoproduction from coastal Louisiana suspended sediments, which, to the best of our knowledge, are the only published AQY spectra of a POM photoproduct. Apparently, AQY data covering more photoproducts and geographic areas are needed to elucidate whether POM photodegradation in marine ecosystems can effectively impact organic matter and elemental cycles and how important this process is in comparison with CDOM photochemistry.

Here we report the measurement of AQY spectra of CO photoproduction from suspended particulate matter (SPM) in the western Canadian Arctic and a direct comparison between the particle- and CDOM-based CO efficiencies. We model CO photoproduction using the AQY spectra obtained and discussed the implication of POM photooxidation for the $\mathrm{CO}$ budget. $\mathrm{CO}$ was targeted for a number of reasons. First, a preliminary study evaluating $\mathrm{CO}$ photoproduction from particles suggested a significant POM-based term (up to $40 \%$ of the CDOM-based component) in both coastal and oligotrophic marine waters (Xie and Zafiriou, 2009). Second, thanks to its low background concentrations and high analytical sensitivity, $\mathrm{CO}$ can be relatively easily and precisely $( \pm 2 \%$ ) quantified (Xie et al., 2002). Thus, even small signal changes due to POM photodegradation should be detectable. Third, the role of $\mathrm{CO}$ as a proxy species for other major but more-difficult-to-measure CDOM photoproducts (e.g. $\mathrm{CO}_{2}$, biolabile carbon) (Miller and Zepp, 1995; Miller et al., 2002; White et al., 2010) could also hold for POM photochemistry. Finally, an assessment of the POM-based CO source helps better understand the physical and biogeochemical functions of this species, since CO is a useful tracer for modeling upper-ocean mixing dynamics (Kettle, 2005), an atmospherically active trace gas emitting from the ocean (Conrad et al., 1982; Stubbins et al., 2006), and an energy source for bacteria oxidizing it (King and Weber, 2007; Moran and Miller, 2007).

\section{Methods}

\subsection{Study area}

The study area encompassed the Mackenzie River estuary (MRE), Mackenzie Shelf (MS), and Canada Basin (CB) in the southeastern (SE) Beaufort Sea (Fig. 1). The area's most prominent hydrographic feature is the Mackenzie River, the only North American analogue to the immense Arctic rivers on the Siberian continent. The Mackenzie River possesses a watershed area of $1680 \mathrm{~km}^{2}$ and delivers to the Arctic Ocean the largest POC $\left(1.8-2.1 \times 10^{12} \mathrm{~g} \mathrm{C} \mathrm{yr}^{-1}\right)$, sixth largest DOC $\left(1.3 \mathrm{~g} \mathrm{Cyr}^{-1}\right)$, and fourth largest freshwater (249-333 $\mathrm{km}^{3} \mathrm{yr}^{-1}$ ) fluxes among all major Arctic rivers (Dittmar and Kattner, 2003). The river flows into the Beaufort Sea through two major passages: the western and eastern 


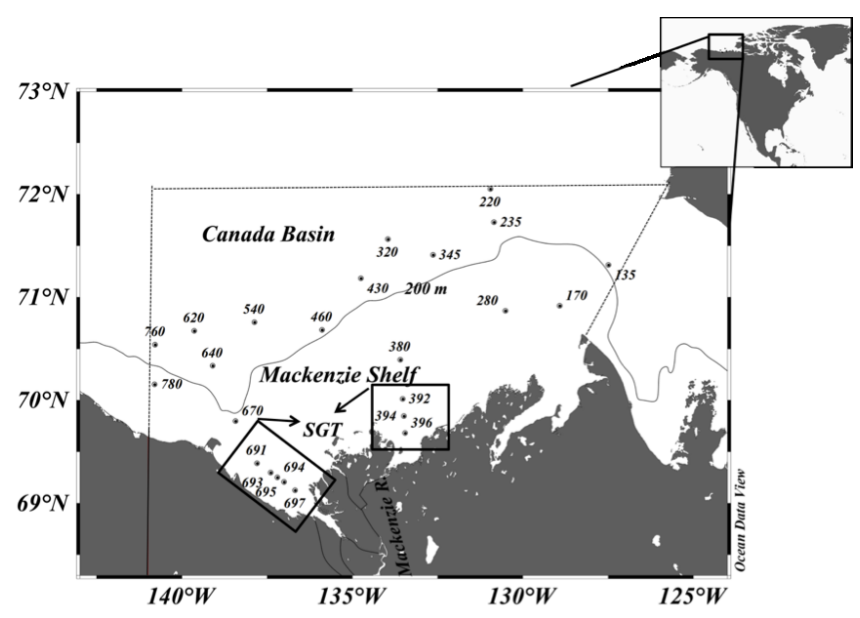

Fig. 1. Sampling map. See Table 1 for detailed sampling information for each station. Solid line is the $200 \mathrm{~m}$ isobath. Dashed line designates the area for which $\mathrm{CO}$ photoproduction rates were modeled. This map was constructed using the online software of Ocean Data View (R. Schlitzer, 2010, unpublished data, http://odv.awi.de).

channels. The river flow, subject to the Coriolis effect, bends to the right toward the Amundsen Gulf under calm conditions but can extend across the shelf into the interior ocean under strong easterly winds (Macdonald et al., 1999). CDOM in surface water is of primarily terrigenous origin on the shelf but has a strong autochthonous signature in the CB (Stedmon et al., 2011). Terrigenous particles dominate within the water column of the river plume, while particles of marine origin prevail outside the plume (Goñi et al., 2005; Forest et al., 2007; Magen et al., 2010). Water column primary production in the SE Beaufort Sea is limited by light availability prior to ice break in early spring, but by nitrogen depletion subsequent to the spring phytoplankton bloom in water masses away from direct riverine and upwelling influences (Tremblay et al., 2008). The exhaustion of surface-water nitrogen typically leads to the formation of deep chlorophyll maxima (DCM) near the nutricline having Pacific summer water characteristics (Tremblay et al., 2008; Matsuoka et al., 2012).

The Western Canadian Arctic is one of the most sensitive regions on Earth to climate warming (Flato et al., 2000). Rising temperatures in this region over the last several decades have supposedly shortened sea ice-cover timespan and reduced sea ice extent (Stroeve et al., 2008), allowing more solar radiation to penetrate into the water column. Interests have since intensified concerning the fate and transformation of the terrigenous organic matter exported to the Arctic Ocean (Opsahl et al., 1999; Hansell et al., 2004; Benner et al., 2005). Photooxidation, a well-known CDOM sink in mid- and low-latitude oceans, has recently been proposed as a potentially significant cycling term of terrigenous CDOM in the western Canadian Arctic seas (e.g. Bélanger et al., 2006; Osburn et al., 2009; Xie et al.,
2009), since declining ice cover, combined with increasing solar UV radiation over the high north (Fioletov et al., 2004; see also website: http://onlinelibrary.wiley.com/doi/10.1002/ wea.700/pdf), enhances the photooxidation potential in the water column.

\subsection{Sampling}

Sampling was conducted during the Mackenzie Light and Carbon (Malina) Program in August 2009 aboard the icebreaker CCGS Amundsen, covering the MS ( $<200 \mathrm{~m}$ deep) and CB (> $200 \mathrm{~m}$ deep) (Fig. 1). A Zodiac boat released from the CCGS Amundsen visited two salinity gradient transects (SGTs) characterized by shallow waters, each in the east (SGT-E) and west (SGT-W) channel of the MRE. SGT samples were collected using a clean high-density polyethylene bucket, transferred into 20-L acid-washed, collapsible polyethylene carboys, and then brought back to the CCGS Amundsen. Shelf and open ocean samples were taken at the surface ( $\sim 3 \mathrm{~m}$ deep) and DCM (mostly $60-75 \mathrm{~m}$ deep) using 12-L Niskin bottles mounted onto a standard conductivitytemperature-depth (CTD) rosette. Detailed sampling information is compiled in Table 1. Niskin and bucket samples were gravity-filtered through Whatman Polycap 75 AS filtration capsules sequentially containing $0.2-\mu \mathrm{m}$ glass microfiber and nylon membrane filters. The filtrates were collected into half-gallon clear glass bottles (Qorpak) for irradiation experiments (see below) and 60-mL clear glass bottles (Qorpak) for CDOM absorbance measurements. The capsules were thoroughly flushed with Nanopure water and then sample water prior to filtration. Unfiltered samples were directly transferred into half-gallon glass bottles for irradiation experiments and 2-L plastic bottles (Nalgene) for chlorophyll $a$ (Chl $a$ ) and particle absorbance determinations. All bottles were protected against light during sample transfer by wrapping them with aluminum foil or black plastic bags. They were all sequentially acid-cleaned with $10 \% \mathrm{HCl}$, profusely washed with Nanopure water, and rinsed with sample water before use. Irradiation experiments and particle optical density (i.e. absorbance) and $\mathrm{Chl} a$ concentration ([Chl $a]$ ) measurements were performed aboard the ship immediately after sample collection. CDOM samples, stored under refrigeration and darkness, were transported to Rimouski at the end of the cruise and analyzed immediately thereafter.

\subsection{Irradiation}

The irradiation procedure and setup were similar to those reported by Zhang et al. (2006). Unfiltered water samples were poisoned with $\mathrm{KCN}\left(4.3 \mu \mathrm{molL}^{-1}\right)$ to eliminate microbial $\mathrm{CO}$ uptake and filtered samples were amended with the same amount of KCN for uniformity of sample treatment. Samples were purged with $\mathrm{CO}$-free air to minimize background CO concentrations, transferred into pre-combusted, quartzwindowed cylindrical cells having an inner diameter of 
Table 1. Sampling information along with salinity and water temperature.

\begin{tabular}{|c|c|c|c|c|c|c|c|c|}
\hline \multirow[t]{2}{*}{ Sub-region $^{\mathrm{a}}$} & \multirow[t]{2}{*}{ Station $^{b}$} & \multirow{2}{*}{$\begin{array}{c}\text { Date of } \\
\text { Aug } 2009\end{array}$} & \multicolumn{2}{|c|}{ Coordinate } & \multirow{2}{*}{$\begin{array}{l}\text { Total water } \\
\text { depth (m) }\end{array}$} & \multirow{2}{*}{$\begin{array}{l}\text { Sampling } \\
\text { depth }(\mathrm{m})^{\mathrm{c}}\end{array}$} & \multirow[t]{2}{*}{ Salinity } & \multirow[t]{2}{*}{ Temp. $\left({ }^{\circ} \mathrm{C}\right)$} \\
\hline & & & Lat., ${ }^{\circ} \mathrm{N}$ & Long., ${ }^{\circ} \mathrm{W}$ & & & & \\
\hline \multirow{4}{*}{ SGT-E } & $392-S$ & 16 & 70.012 & 133.522 & 27 & 0 & 27.902 & 3.2 \\
\hline & $394-S 1$ & 3 & 69.847 & 133.492 & 14 & 3.5 & 25.311 & 7.1 \\
\hline & $394-S 2$ & 16 & 69.846 & 133.490 & 12 & 0 & 21.455 & 7.8 \\
\hline & $396-S$ & 16 & 69.680 & 133.458 & 6.3 & 0 & 17.267 & 8.2 \\
\hline \multirow{6}{*}{ SGT-W } & $691-S$ & 13 & 69.387 & 137.792 & 44 & 0 & 23.612 & 5.2 \\
\hline & $692-S$ & 13 & 69.342 & 137.594 & 39 & 0 & 22.184 & 5.9 \\
\hline & $693-S$ & 13 & 69.296 & 137.398 & 32 & 0 & 15.003 & 8.8 \\
\hline & $694-S$ & 13 & 69.251 & 137.202 & 9.0 & 0 & 9.426 & 9.3 \\
\hline & $695-S$ & 13 & 69.204 & 137.006 & 5.0 & 0 & 7.042 & 9.3 \\
\hline & $697-S$ & 13 & 69.125 & 136.681 & 1.7 & 0 & 0.154 & 10.3 \\
\hline \multirow{8}{*}{ MS } & $170-S$ & 7 & 70.917 & 128.919 & 35 & 3.0 & 29.009 & 3.8 \\
\hline & $280-S$ & 4 & 70.869 & 130.507 & 38 & 3.3 & 27.558 & 4.8 \\
\hline & 280-D & 4 & 70.869 & 130.507 & 38 & 24 & 31.931 & -0.0 \\
\hline & $380-S$ & 8 & 70.393 & 133.595 & 62 & 6.0 & 27.611 & 4.1 \\
\hline & 380-D & 8 & 70.393 & 133.595 & 62 & 48 & 31.924 & -1.1 \\
\hline & $670-S$ & 10 & 69.797 & 138.428 & 173 & 3.0 & 23.500 & 4.0 \\
\hline & $780-S$ & 12 & 70.154 & 140.801 & 50 & 3.0 & 22.845 & 3.6 \\
\hline & 780-D & 12 & 70.154 & 140.801 & 50 & 30 & 31.685 & -1.1 \\
\hline \multirow{17}{*}{$\mathrm{CB}$} & $135-\mathrm{D}$ & 20 & 71.312 & 127.489 & 230 & 60 & 31.505 & -1.3 \\
\hline & $220-S$ & 5 & 70.050 & 130.945 & 225 & 3.0 & 27.137 & -0.8 \\
\hline & 220-D & 5 & 70.050 & 130.945 & 225 & 70 & 31.534 & -1.4 \\
\hline & $235-\mathrm{D}$ & 23 & 71.728 & 130.842 & 611 & 75 & 31.965 & -1.1 \\
\hline & $320-S$ & 9 & 71.562 & 133.958 & 1115 & 2.8 & 26.462 & -0.7 \\
\hline & $320-\mathrm{D}$ & 9 & 71.562 & 133.958 & 1115 & 70 & 31.546 & -1.2 \\
\hline & $345-\mathrm{D}$ & 15 & 71.410 & 132.638 & 580 & 60 & 31.276 & -1.0 \\
\hline & $430-S$ & 18 & 71.184 & 134.748 & 1300 & 3.0 & 26.002 & -0.8 \\
\hline & 430-D & 18 & 71.184 & 134.748 & 1300 & 65 & 31.779 & -1.1 \\
\hline & $460-S$ & 19 & 70.682 & 135.891 & 362 & 3.0 & 24.731 & -0.1 \\
\hline & 460-D & 19 & 70.682 & 135.891 & 362 & 56 & 31.261 & -1.0 \\
\hline & $540-\mathrm{S}$ & 17 & 70.756 & 137.871 & 1522 & 3.0 & 25.292 & -0.5 \\
\hline & 540-D & 17 & 70.756 & 137.871 & 1522 & 70 & 31.808 & -1.1 \\
\hline & $620-S$ & 11 & 70.674 & 139.634 & 1538 & 3.0 & 20.751 & 2.9 \\
\hline & $640-S$ & 11 & 70.334 & 139.099 & 550 & 3.3 & 21.428 & 3.3 \\
\hline & $760-S$ & 12 & 70.540 & 140.785 & 566 & 3.1 & 22.173 & 0.4 \\
\hline & 760-D & 12 & 70.540 & 140.785 & 566 & 70 & 31.475 & -1.1 \\
\hline
\end{tabular}

${ }^{\text {a }}$ SGT-E $(\mathrm{W})=$ salinity gradient transect-east (west) channel; MS = Mackenzie Shelf; $\mathrm{CB}=$ Canada Basin (see text and Fig. 1 for definitions).

b $\mathrm{S}=$ surface; $\mathrm{D}=\mathrm{DCM}$ (deep chlorophyll maximum).

c $0 \mathrm{~m}$ indicates bucket samples; all other depths indicate Niskin bottle samples.

$3.4 \mathrm{~cm}$ and a length of $11.4 \mathrm{~cm}$. The quartz cells were closed without headspace and placed vertically in a temperaturecontrolled $\left(4^{\circ} \mathrm{C}\right)$ incubator, and irradiated using a SUNSET XLS+ solar simulator equipped with a $1.5 \mathrm{~kW}$ xenon lamp. The side walls of the cells were wrapped with black electric tape to prevent lateral light interference between the cells. Radiation reaching the sample was essentially collimated and perpendicular to the irradiation surface (see Supporting Information in the study by Zhang et al., 2006). Parallel dark controls served to evaluate any thermal effects on $\mathrm{CO}$ production. A series of successive Schott long-band cutoff filters, with model numbers of WG280, WG295, WG320, WG345, GG395, GG435, and GG495, were employed to evaluate the wavelength dependence of $\mathrm{CO}$ photoproduction. The numeric value in each model number signifies the nominal $50 \%$ transmittance cutoff wavelength in nanometers. Spectral photon fluxes impinging onto the window of each quartz cell were measured at $1 \mathrm{~nm}$ intervals using an OL-754 spectroradiometer fitted with a 2-inch OL IS- 270 integrating sphere. The variability of the lamp output across the UV and 
visible regimes was within $4 \%$ throughout the entire cruise. Irradiation lasted from $10 \mathrm{~min}$ to $3.0 \mathrm{~h}$ (mostly $<2.0 \mathrm{~h}$ ) for samples under cutoff filters WG280, WG295, and WG320 and from $10 \mathrm{~min}$ to $12.0 \mathrm{~h}$ for samples under the remaining longer cutoff filters. Estuarine and coastal samples were subject to shorter durations of exposure compared to open-ocean samples. Because of short irradiations and lack of significant photobleaching (Fig. S1 in the Supplement), CO production rate was assumed to be constant within the irradiation times. For the same reasons, the effect of self-shading (Hu et al., 2002) in the two UV-optically thick samples (Sta. 697 and Sta. 695) was considered negligible. To minimize particle settling during irradiation, the cells were adequately shaken just before irradiation. Few particles were seen on the bottom of the cell after irradiation even for those stations with high particle loads (e.g. Sta. 697 and Sta. 695) due again to the very short irradiation durations (10 min for Sta. 697 and 15 min for Sta. 695).

\subsection{Analyses}

$\mathrm{CO}$ concentrations were measured using the headspace method reported by Xie et al. (2002). Briefly, post-irradiation samples were transferred to a $50-\mathrm{mL}$ glass syringe, into which 5-mL CO-free air was introduced to obtain a 1:6 gas: water ratio. The syringe was vigorously shaken for $3 \mathrm{~min}$ and the equilibrated headspace gas was injected into a TA3000 Reduction Gas Analyzer (Trace Analytical) for CO quantification. The analyzer was standardized by frequent injections of a National Institute of Standards and Technology (NIST)-traceable gaseous CO standard of 1.23 parts per million by volume (Praxair). To be consistent with the samples' relative humidity $(100 \%)$, the dry CO standard was drawn into a wetted $10-\mathrm{mL}$ glass before injection. The amount of $\mathrm{CO}$ photochemically produced was calculated as the difference in $\mathrm{CO}$ concentration between the irradiated sample and the parallel dark control. The uncertainty of $\mathrm{CO}$ measurement is within $\pm 2 \%$ (Xie et al., 2002).

For Chl $a$ quantification, water samples $(250-1000 \mathrm{~mL})$ were filtered through pre-combusted $25-\mathrm{mm}$ GF/F filters (Whatman) under low vacuum $(<50 \mathrm{kPa})$. The particlesretained filters were placed in $10 \mathrm{~mL}$ of $90 \%$ acetone in scintillation vials for at least $18 \mathrm{~h}$ in the dark at $4{ }^{\circ} \mathrm{C}$. The supernatants were analyzed for fluorescence before and after being acidified with $100 \mu \mathrm{L}$ of $5 \% \mathrm{HCl}$, using a Turner Designs fluorometer (model 10-AU) according to the method of Parsons et al. (1984). [Chl $a$ ]s were calculated using the equation of Holm-Hansen et al. (1965).

Water samples $(5.0-2735 \mathrm{~mL})$ for particle optical density measurement were subjected to the same filtration procedure as that for Chl $a$ determination. Particulate matter collected on the filters was analyzed for optical density using a Perkin Elmer Lambda 19 dual beam spectrometer fitted with a 150$\mathrm{mm}$ integrating sphere (Labsphere) accommodating a homemade filter holder (Röttgers and Gehnke, 2012). The spectral optical density of the filter, $\mathrm{OD}_{\mathrm{f}, \lambda}$, where $\lambda$ is wavelength in nanometers, was recorded from 800 to $300 \mathrm{~nm}$ at $1-\mathrm{nm}$ increments and a scanning speed of $120 \mathrm{~nm} \mathrm{~min}^{-1} . \mathrm{OD}_{\mathrm{f}, \lambda}$ was converted to the spectral particulate absorption coefficient, $a_{\mathrm{p}, \lambda}\left(\mathrm{m}^{-1}\right)$, using Eq. (1),

$a_{\mathrm{p}, \lambda}=2.303 \times(A / V) \times\left(\mathrm{OD}_{\mathrm{f}, \lambda}-\mathrm{OD}_{\text {blank }, \lambda}\right) \times\left(1 / \beta_{\lambda}\right)$

where $\mathrm{OD}_{\text {blank, } \lambda}$ is the optical density of a blank filter, $A$ the clearance area of particles on the filter $\left(\mathrm{m}^{2}\right), V$ the volume of sample water filtered $\left(\mathrm{m}^{3}\right)$, and $\beta_{\lambda}$ the path length amplification factor. Here we fitted $\beta_{\lambda}$ nonlinearly to $\mathrm{OD}_{\mathrm{f}, \lambda}$ (Röttgers and Gehnke, 2012):

$\beta_{\lambda}=2.9 \mathrm{OD}_{\mathrm{f}, \lambda}^{2}-4.76 \mathrm{OD}_{\mathrm{f}, \lambda}+4.5$

Upon the completion of $a_{\mathrm{p}, \lambda}$ determination, the filter was dipped in $10 \mathrm{~mL}$ methanol for $\sim 18 \mathrm{~h}$ to bleach pigments and the absorption coefficient of non-algal particles, $a_{\text {nap }, \lambda}$ $\left(\mathrm{m}^{-1}\right)$, was determined in the same manner as that for $a_{\mathrm{p}, \lambda}$. Data of $a_{\mathrm{p}, \lambda}$ and $a_{\mathrm{nap}, \lambda}$ between 250 and $299 \mathrm{~nm}$ were extrapolated from the exponential fits of $a_{\mathrm{p}, \lambda}$ and $a_{\mathrm{nap}, \lambda}$ to wavelength over the range from $300-420 \mathrm{~nm}$. Subtracting $a_{\mathrm{nap}, \lambda}$ from $a_{\mathrm{p}, \lambda}$ gave the phytoplankton absorption coefficient, $a_{\mathrm{phy}, \lambda}\left(\mathrm{m}^{-1}\right)$. More details of particulate absorption measurement can be found in the study of Doxaran et al. (2012).

The spectral optical density of $\mathrm{CDOM}, \mathrm{OD}_{\mathrm{cdom}, \lambda}$, was scanned from 800 to $200 \mathrm{~nm}$ at $1-\mathrm{nm}$ intervals using a Perkin-Elmer Lambda 35 dual beam spectrophotometer fitted with a 5-cm quartz flow cell and referenced to highperformance-liquid-chromatography (HPLC) grade pure water (Ricca Chemical). Samples were allowed to warm up to room temperature before analysis. The flow cell was rinsed with methanol, pure water, and sample water between individual scans. A baseline correction was applied by subtracting the optical density averaged over $683-687 \mathrm{~nm}$ from all $\mathrm{OD}_{\text {cdom, } \lambda}$ values (Babin et al., 2003). The spectral CDOM absorption coefficient, $a_{\mathrm{cdom}, \lambda}\left(\mathrm{m}^{-1}\right)$, was calculated as 2.303 times $\mathrm{OD}_{\text {cdom, } \lambda}$ divided by the light path length of the cell in meters $(0.05 \mathrm{~m})$. The lower detection limit of $a_{\mathrm{cdom}, \lambda}$ determination, defined as three times the standard deviation of five replicate analyses of pure water, was $0.02 \pm 0.01 \mathrm{~m}^{-1}$ over $250-700 \mathrm{~nm}$.

\subsection{Retrieval of CO AQY}

The spectral CO AQY, $\Phi_{\lambda}$, is defined as the number of moles of $\mathrm{CO}$ produced per mole of photons absorbed by a given set of light-absorbing materials at wavelength $\lambda$. Here the light-absorbing materials refer to CDOM, particles, and CDOM plus particles, corresponding to $\Phi_{\lambda}$ for $\operatorname{CDOM}\left(\Phi_{\text {cdom }, \lambda}\right)$, particles $\left(\Phi_{\mathrm{p}, \lambda}\right)$, and total dissolved and particulate matter $\left(\Phi_{\mathrm{t}, \lambda}\right)$, respectively. According to $\mathrm{Hu}$ et al. (2002), the number of absorbed photons at wavelength $\lambda$, $Q_{\mathrm{a}, \lambda}$ (mol photons s ${ }^{-1} \mathrm{~nm}^{-1}$ ) was calculated using Eq. (3):

$Q_{\mathrm{a}, \lambda}=Q_{\lambda} \times S \times\left(a_{\lambda} / a_{\mathrm{t}, \lambda}\right) \times\left[1-\exp \left(-a_{\mathrm{t}, \lambda} \times L\right)\right]$ 
$Q_{\lambda}$ (mol photons $\mathrm{m}^{-2} \mathrm{~s}^{-1} \mathrm{~nm}^{-1}$ ) denotes the photon flux just below the frontal quartz window; $a_{\lambda}\left(\mathrm{m}^{-1}\right)$ stands for $a_{\mathrm{cdom}, \lambda}$ for filtered samples or $a_{\mathrm{cdom}, \lambda}$ plus $a_{\mathrm{p}, \lambda}$ for unfiltered samples; $a_{\mathrm{t}, \lambda}\left(\mathrm{m}^{-1}\right)$ is the total absorption coefficient, i.e. $a_{\mathrm{cdom}, \lambda}$ plus the absorption coefficient of pure water, $a_{\mathrm{w}, \lambda}\left(\mathrm{m}^{-1}\right)$ (Buiteveld et al., 1994; Pope and Fry, 1997), for filtered samples or the sum of $a_{\mathrm{cdom}, \lambda}, a_{\mathrm{p}, \lambda}$, and $a_{\mathrm{w}, \lambda}$ for unfiltered seawater; $S\left(\mathrm{~m}^{2}\right)$ and $L(\mathrm{~m})$ are, respectively, the cross-section and path length of the irradiation cells. In unfiltered samples, particle scattering could deflect photons out of the irradiation cell and change the effective path length of light transmission (Miller and Zepp, 1979; Estapa et al., 2012a). The contribution of particle scattering to light attenuation in unfiltered samples was estimated from Monte Carlo simulations using the SimulO software (Leymarie et al., 2010; see Supplement). The results indicated that the effect of particle scattering across the $280-600 \mathrm{~nm}$ wavelength range was $\leq 0.3 \%$ in the $\mathrm{CB}$ and $\leq 1.9 \%$ on the MS, including the two outermost stations along the SGTs (Sta. 392 and 691). Samples from the remaining SGT stations had larger $a_{\mathrm{t}}$ values (1.00-10.45 $\mathrm{m}^{-1}$ at $\left.412 \mathrm{~nm}\right)$ and higher scattering to absorption ratios (2.8-9.8 at $412 \mathrm{~nm}$ ). The effect of particle scattering for these stations ranged from $2.0 \%$ to $27.8 \%$, depending on sampling location and wavelength (Fig. S4 in the Supplement). Positive values indicate an overestimate of light absorption by Eq. (3) due to photons being scattered out of the cell. Scattering effects of $\geq 2 \%$ were accounted for in the calculation of absorbed photons.

$\Phi_{\mathrm{cdom}, \lambda}$ and $\Phi_{\mathrm{t}, \lambda}$ were obtained with an iterative curve-fit protocol developed by Johannessen and Miller (2001) and modified by Zhang et al. (2006). Briefly, this method assigned a quasi-exponential form with unknown parameters to express the change of $\Phi_{\lambda}\left(\Phi_{\mathrm{cdom}, \lambda}\right.$ or $\left.\Phi_{\mathrm{t}, \lambda}\right)$ as a function of wavelength (Zhang et al., 2006; Xie et al., 2009):

$\Phi_{\lambda}=m_{1} \times \exp \left[m_{2} /\left(\lambda+m_{3}\right)\right]$

where $m_{1}, m_{2}$, and $m_{3}$ are fitting parameters. The amount of $\mathrm{CO}$ produced in an irradiation cell over the exposure time could then be predicted as the product of the assumed $\Phi_{\lambda}$ function and the number of absorbed photons integrated over $250-600 \mathrm{~nm}$. The optimum values of the unknown parameters in Eq. (3) were computed by varying these parameters from initial estimates until the minimum difference between the measured and predicted production is achieved. CO production rates calculated from the retrieved $\Phi_{\lambda}$ were in good agreement with the measured rates, with $R^{2}$ ranging from 0.969 to 0.998 (mean: 0.991) for filtered samples and from 0.982 to 0.998 (mean: 0.992) for unfiltered samples. Ziolkowski and Miller (2007) validated the multispectral curve fitting approach as adopted here against the conventional monochromatic method for $\mathrm{CO}$ photoproduction. Note that our experiment could not resolve fine $\Phi_{\lambda}$ features for unfiltered samples in the long visible, where $\mathrm{Chl} a$ presents an absorption peak at ca. $675 \mathrm{~nm}$, since our longest cutoff wavelength was $495 \mathrm{~nm}$ (see Sect. 2.3). Any potential CO pro- duction at $>600 \mathrm{~nm}$ was ascribed to the visible wavelengths $<600 \mathrm{~nm}$.

$\Phi_{\mathrm{p}, \lambda}$ can be derived from $\Phi_{\mathrm{cdom}, \lambda}$ and $\Phi_{\mathrm{t}, \lambda}$ per the following mathematical manipulations. The spectral $\mathrm{CO}$ photoproduction rate in an unfiltered sample, $P_{\mathrm{t}, \lambda}$ $\left(\operatorname{molCO}{ }^{-1} \mathrm{~nm}^{-1}\right)$, can be expressed as

$P_{\mathrm{t}, \lambda}=\Phi_{\mathrm{t}, \lambda} \times Q_{\mathrm{t}, \mathrm{a}, \lambda}$

$P_{\mathrm{t}, \lambda}$ is the sum of $\mathrm{CO}$ photoproduction from CDOM, $P_{\text {cdom }, \lambda}\left(\mathrm{mol} \mathrm{CO} \mathrm{s}^{-1} \mathrm{~nm}^{-1}\right)$, and that from particles, $P_{\mathrm{p}, \lambda}$ $\left(\mathrm{molCO} \mathrm{s}^{-1} \mathrm{~nm}^{-1}\right)$, i.e.,

$P_{\mathrm{t}, \lambda}=P_{\text {cdom }, \lambda}+P_{\mathrm{p}, \lambda}$

$P_{\text {cdom }, \lambda}$ and $P_{\mathrm{p}, \lambda}$ are given by

$P_{\text {cdom }, \lambda}=\Phi_{\text {cdom }, \lambda} \times Q_{\text {cdom }, \mathrm{a}, \lambda}$

and

$P_{\mathrm{p}, \lambda}=\Phi_{\mathrm{p}, \lambda} \times Q_{\mathrm{p}, \mathrm{a}, \lambda}$

Substituting Eqs. (5), (7) and (8) into Eq. (6) and rearranging it give

$\Phi_{\mathrm{p}, \lambda}=\Phi_{\mathrm{t}, \lambda}+\left(\Phi_{\mathrm{t}, \lambda}-\Phi_{\mathrm{cdom}, \lambda}\right) \times\left(a_{\mathrm{cdom}, \lambda} / a_{\mathrm{p}, \lambda}\right)$

$Q_{\mathrm{t}, \mathrm{a}, \lambda}, Q_{\mathrm{cdom}, \mathrm{a}, \lambda}$ and $Q_{\mathrm{p}, \mathrm{a}, \lambda}$ in Eqs. (5), (7) and (8) denote the number of photons absorbed by CDOM plus particles, CDOM, and particles, respectively, in an unfiltered sample as defined by Eq. (3).

To facilitate comparison of various $\Phi_{\lambda}$ spectra, a solar irradiance spectrum-weighted mean apparent quantum yield, $\bar{\Phi}$, was computed for each CO AQY spectrum following the procedure of Xie et al. (2009):

$\bar{\Phi}=\left(\int_{290}^{600} Q_{0, \lambda} \times \Phi_{\lambda} \times \mathrm{d} \lambda\right) /\left(\int_{290}^{600} Q_{0, \lambda} \times \mathrm{d} \lambda\right)$

$\bar{\Phi}$ denotes $\bar{\Phi}_{\text {cdom }}$ for CDOM, $\bar{\Phi}_{\mathrm{p}}$ for particles, and $\bar{\Phi}_{\mathrm{t}}$ for CDOM plus particles. $Q_{0, \lambda}$ (mol photons $\mathrm{m}^{-2} \mathrm{~h}^{-1} \mathrm{~nm}^{-1}$ ) is the surface spectral solar photon fluxes at $70^{\circ} \mathrm{N}, 133^{\circ} \mathrm{W}$ at 14:00 LT on 1 July, simulated using the SMARTS model (Simple Model of the Atmospheric Radiative Transfer of Sunshine; Gueymard, 2001) under mid-summer Arctic atmospheric and cloudless conditions with an ozone column burden of 330 Dobson Units. This normalization reduced the AQY spectrum to a single value of $\mathrm{CO}$ production in the entire water column, in which all solar radiation over $290-600 \mathrm{~nm}$ was absorbed by a specific group of lightabsorbing material, i.e. CDOM, particles, or the sum of the two (Bélanger et al., 2006). 
Table 2. Means and ranges (in the parentheses) of salinity, temperature, [Chl $a$ ], $a_{\mathrm{cdom}, 412,} a_{\mathrm{p}, 412}$, and $a_{\mathrm{phy}, 412}: a_{\mathrm{p}, 412}$. Keys in the sub-region column are the same as those in Table 1.

\begin{tabular}{lcccccc}
\hline Sub-region & Salinity & $\begin{array}{c}\text { Temp. } \\
\left({ }^{\circ} \mathrm{C}\right)\end{array}$ & $\begin{array}{c}{[\mathrm{Chl} a]} \\
(\mu \mathrm{g} \mathrm{L}-1)\end{array}$ & $\begin{array}{c}a_{\mathrm{cdom}, 412} \\
\left(\mathrm{~m}^{-1}\right)\end{array}$ & $\begin{array}{c}a_{\mathrm{p}, 412} \\
\left(\mathrm{~m}^{-1}\right)\end{array}$ & $a_{\mathrm{phy}, 412}: a_{\mathrm{p}, 412}$ \\
\hline SGT-E & 22.98 & 6.4 & 1.4 & 0.69 & 0.22 & 0.13 \\
SGT-W & $(17.27-27.90)$ & $(3.2-8.2)$ & $(0.65-2.5)$ & $(0.12-1.11)$ & $(0.038-0.36)$ & $(0.07-0.18)$ \\
& 12.90 & 8.6 & 1.9 & 1.30 & 2.65 & 0.16 \\
MS-surface & $(0.15-23.61)$ & $(5.2-10.3)$ & $(0.17-3.2)$ & $(0.39-2.04)$ & $(0.053-8.40)$ & $(0.06-0.28)$ \\
MS-DCM & 26.10 & 4.1 & 2.0 & 0.22 & 0.076 & 0.25 \\
CB-surface & $(22.85-29.10)$ & $(3.6-4.8)$ & $(0.08-7.6)$ & $(0.13-0.33)$ & $(0.017-0.26)$ & $(0.13-0.41)$ \\
& 31.85 & -0.7 & 3.8 & 0.17 & 0.14 & $0.46(0.22-0.66)$ \\
CB-DCM & 24.25 & $(-0.006$ to -1.1$)$ & $(1.3-8.0)$ & $(0.14-0.22)$ & $(0.085-0.25)$ & 0.40 \\
& $(31.26-31.96)$ & $(-1.0$ to -1.4$)$ & $(0.12-0.71)$ & $(0.10-0.23)$ & $(0.009-0.025)$ & $(0.56-0.88)$ \\
\hline
\end{tabular}

\section{Results and discussion}

\subsection{General physical, biological, and chemical settings}

Salinity, temperature, $[\mathrm{Chl} a]$, and absorption coefficients of various constituents are shown in Table 2. Surface salinity along the SGT-W monotonically increased seaward from 0.15 at Sta. 697 to 23.61 at Sta. 691. The SGT-E covered a much narrower salinity range from 17.27 at Sta. 396 to 27.90 at Sta. 392. The lower mean surface salinity in the CB than that on the MS suggests a stronger influence of sea ice melting in the CB. Surface temperature along the SGTs displayed a trend inverse to salinity, decreasing seaward from $10.3{ }^{\circ} \mathrm{C}$ to $5.2{ }^{\circ} \mathrm{C}$ along the SGT-W and from $8.2{ }^{\circ} \mathrm{C}$ to $3.2^{\circ} \mathrm{C}$ across the SGT-E; temperature further decreased from the MS to CB. Mean salinity and temperature of the DCM samples were 31.64 and $-1.0^{\circ} \mathrm{C}$, respectively, typical of Pacific summer water origin (McLaughlin, 1996; Matsouka et al., 2012).

[Chl $a$ ] generally decreased from nearshore to offshore at both the surface and DCM. The highest value $\left(7.6 \mu \mathrm{g} \mathrm{L}^{-1}\right)$ in the surface occurred at Sta. 170 located within the upwelling zone off Cape Bathurst (Williams and Carmack, 2008). Mean [Chl $a$ ]s at the DCM were $3.8 \mu \mathrm{g} \mathrm{L}^{-1}$ on the $\mathrm{MS}$ and $0.42 \mu \mathrm{g} \mathrm{L}^{-1}$ in the $\mathrm{CB}$, being 2.4 and 5.2 times their surface values.

The absorption coefficients of CDOM and particles at the surface, as exemplified by $a_{\mathrm{cdom}, 412}$ and $a_{\mathrm{p}, 412}$, diminished rapidly from the estuary to the MS and $\mathrm{CB}$, indicating a strong influence of the riverine input of dissolved and particulate materials. The highest $a_{\mathrm{cdom}, 412}$ and $a_{\mathrm{p}, 412}$ both occurred at Sta. $697\left(a_{\mathrm{cdom}, 412}: 2.04 \mathrm{~m}^{-1} ; a_{\mathrm{p}, 412}: 8.40 \mathrm{~m}^{-1}\right)$ and the lowest in the ice melt-influenced water at Sta. 430 $\left(a_{\text {cdom, } 412}: 0.07 \mathrm{~m}^{-1} ; a_{\mathrm{p}, 412}: 0.004 \mathrm{~m}^{-1}\right)$. Relatively high $a_{\text {cdom, } 412}\left(0.20 \mathrm{~m}^{-1}\right)$ and $a_{\mathrm{p}, 412}\left(0.26 \mathrm{~m}^{-1}\right)$ values were observed in the upwelling zone (Sta. 170). At the DCM, $a_{\text {cdom, } 412}$ was fairly constant throughout the MS and CB; $a_{\mathrm{p}, 412}$ was more variable with the mean value for the MS being nine times that for the CB. The $a_{\mathrm{phy}, 412}: a_{\mathrm{p}, 412}$ ratio increased from nearshore to offshore, with the lowest occurring at Sta. 697 (0.06) and the highest at Sta. 430 (0.66). The mean $a_{\mathrm{phy}, 412}: a_{\mathrm{p}, 412}$ at the DCM was $\sim 2$ times that at the surface in both the MS and CB.

\subsection{CO AQY spectra}

Fitted parameters for Eq. (3) are shown in Table 3 and typical $\Phi_{\text {cdom }, \lambda}$ and $\Phi_{\mathrm{p}, \lambda}$ spectra are displayed in Fig. 2. $\Phi_{\mathrm{p}, \lambda}$ at the innermost Sta. 697 on the SGT-W was lower than $\Phi_{\text {cdom, } \lambda}$, the difference being pronounced in the UV-A wavelengths. At Sta. 280 on the MS and Sta. 430 in the CB, surface water $\Phi_{\mathrm{p}, \lambda}$ was higher than $\Phi_{\mathrm{cdom}, \lambda}$ at $\lambda>330 \mathrm{~nm}$, with the difference increasing with wavelength. Similarly, $\Phi_{\mathrm{p}, \lambda}$ at the DCM both on the MS (Sta. 280) and in the CB (Sta. 345) exceeded $\Phi_{\text {cdom }, \lambda}$ by large extents over most spectral regimes (Fig. 2). Unlike the rather smooth spectral shape of $\Phi_{\mathrm{p}, \lambda}$ for the estuarine sample (Sta. 697), the spectral patterns of $\Phi_{\mathrm{p}, \lambda}$ for the more marine samples, particularly those from the DCM, were characterized by conspicuous shoulders over the $500-600 \mathrm{~nm}$ band. This attribute might be linked to specific compounds with high photoreactivity in the DCM samples. However, as the spectral pattern of $\Phi_{\mathrm{p}, \lambda}$ determined in the present study was primarily defined by the assumed spectral shapes of $\Phi_{\mathrm{cdom}, \lambda}$ and $\Phi_{\mathrm{t}, \lambda}$ (Eqs. (4), more studies using monochromatic irradiations are needed to confirm or further resolve these fine spectral features.

Figure 3 compares $\bar{\Phi}$ among the three sub-regions and between the surface and DCM. Mean surface water $\bar{\Phi}_{\text {cdom }}$ dropped by $\sim 40 \%$ from the estuary to the MS but only slightly decreased from the MS to the CB $(6 \%)$. On the contrary, mean surface water $\bar{\Phi}_{\mathrm{p}}$ in the estuary $\left(0.93 \times 10^{-6}\right)$ was comparable to that on the shelf $\left(0.98 \times 10^{-6}\right)$ but it 


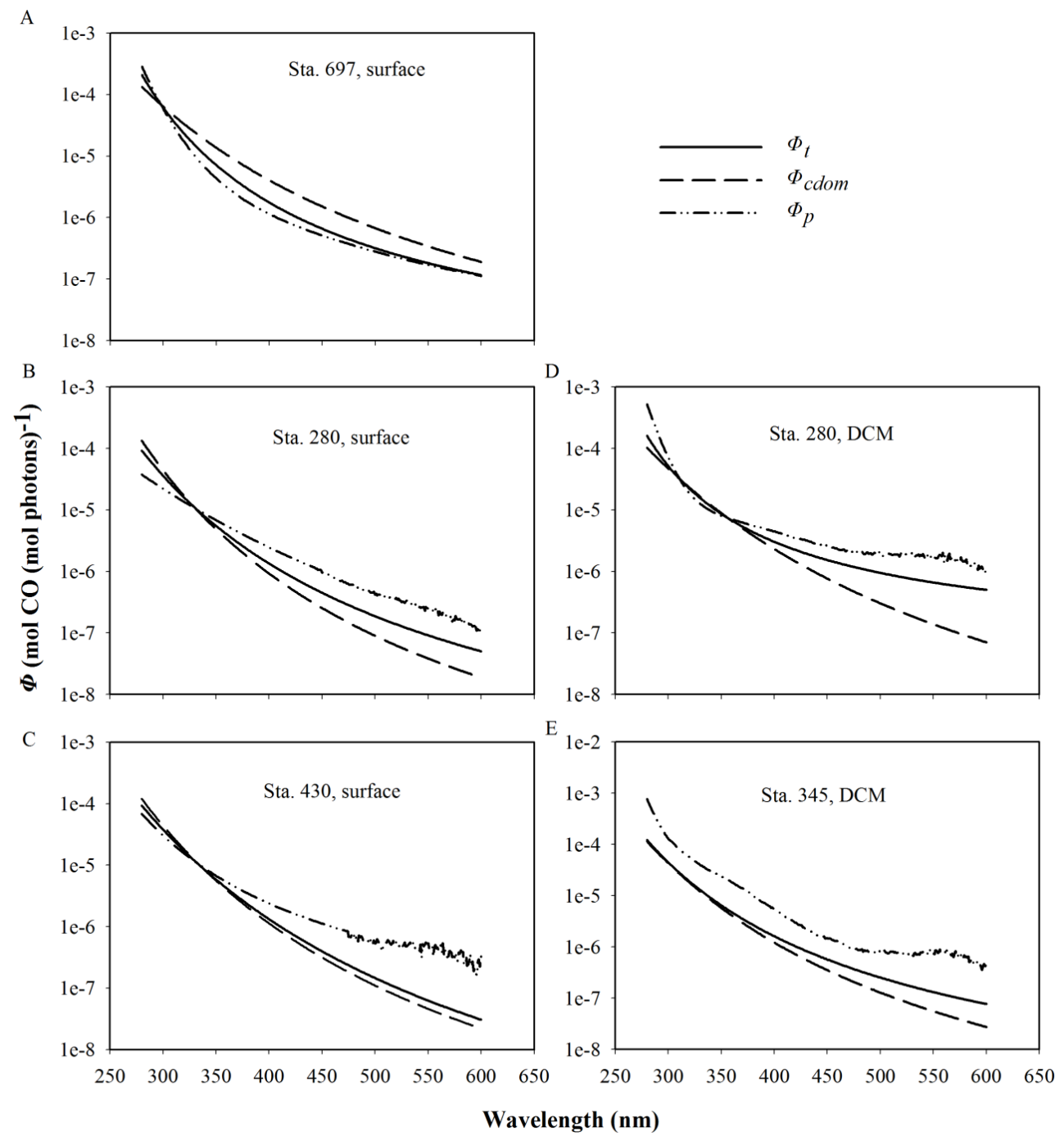

Fig. 2. Typical $\Phi_{\mathrm{cdom}, \lambda}, \Phi_{\mathrm{p}, \lambda}$, and $\Phi_{\mathrm{t}, \lambda}$ spectra from the Mackenzie River estuary (Sta. 697), Mackenzie Shelf (Sta. 280), and Canada Basin (Sta. 345 and 430).

increased to $1.46 \times 10^{-6}$ in the $\mathrm{CB}$. At the DCM, the mean $\bar{\Phi}_{\text {cdom }}$ on the MS $\left(1.14 \times 10^{-6}\right)$ was marginally higher than the mean $\bar{\Phi}_{\text {cdom }}$ in the $\mathrm{CB}\left(1.04 \times 10^{-6}\right)$ while an opposing trend was observed for the mean $\bar{\Phi}_{\mathrm{p}}$ (MS: $1.51 \times 10^{-6}$ vs. CB: $2.21 \times 10^{-6}$ ). $\bar{\Phi}_{\text {cdom }}$ and $\bar{\Phi}_{\mathrm{p}}$ at the DCM were higher than their surface counterparts. The ratio of $\bar{\Phi}_{\mathrm{p}}$ to $\bar{\Phi}_{\text {cdom }}$ was $<1$ in the estuary (0.6) but $>1$ in shelf and offshore waters at both the surface and DCM (range: 1.3-2.1). Surface and DCM samples exhibited comparable $\bar{\Phi}_{\mathrm{p}}: \bar{\Phi}_{\text {cdom }}$ with the highest values seen in the CB.

$\bar{\Phi}_{\text {cdom }}$ along the SGTs was positively and linearly correlated with $a_{\text {cdom }}$ (Fig. 4a), consistent with previous findings (Xie et al., 2009; Stubbins et al., 2011). $\bar{\Phi}_{\text {cdom data }}$ from the MS and CB corresponded to a narrow $a_{\text {cdom }}$ range $\left(0.07-0.33 \mathrm{~m}^{-1}\right.$ at $\left.412 \mathrm{~nm}\right)$ and were scattered with respect to $a_{\text {cdom. }}$. The mean of the surface water $\bar{\Phi}_{\text {cdom }}$ data essentially followed the SGTs' regression line while at the DCM mean
$\bar{\Phi}_{\text {cdom was well (61\%) above it. Unlike }} \bar{\Phi}_{\text {cdom }}, \bar{\Phi}_{\mathrm{p}}$ showed no significant relationships with particulate optical properties such as $a_{\mathrm{p}}$ (Fig. 4b), $a_{\text {phy }}$, and $a_{\text {phy }}: a_{\mathrm{p}}$ (data not shown), neither did it correlate to the mass ratio of particulate organic carbon (POC) to SPM $\left(R^{2}=0.056, p=0.23, n=26\right)$ as obtained by Doxaran et al. (2012) from the same cruise. Hence, particle-based $\mathrm{CO}$ photoproduction appeared to be controlled by more complex mechanisms implicating various factors such as the origin and diagenetic state of POM, the abundance and speciation of photoreactive metals contained in the particles (see Sect. 3.3), and environmental variables (e.g. $\mathrm{pH}$, salinity and temperature).

It should be pointed out that $\mathrm{KCN}$ used for poisoning samples (see Sect. 2.3), though transparent to UV and visible light, suppresses $\mathrm{CO}$ photoproduction (Xie and Zafiriou, 2009). Previous tests indicated that addition of $43.0 \mu \mathrm{mol} \mathrm{L}^{-1} \mathrm{KCN}$ to filtered seawater samples from a 
Table 3. Fitted parameters for equation $\Phi_{\lambda}=m_{1} \times \exp \left(m_{2} /\left(\lambda+m_{3}\right)\right)$ (Eq. 4 in the text) for filtered (CDOM) and unfiltered (CDOM plus particles) samples, along with $\Phi_{330}$ and $\bar{\Phi}$ for CDOM, CDOM plus particles, and particles. n.d. $=$ not determined. The uncertainty for $\Phi_{330}$ and $\bar{\Phi}$ was estimated to be $\pm 4.5 \%$ based on the combined variability of $\mathrm{CO}$ and light intensity measurements.

\begin{tabular}{|c|c|c|c|c|c|c|c|c|c|c|c|c|}
\hline \multirow{2}{*}{ Station } & \multicolumn{5}{|c|}{ Filtered sample (CDOM) } & \multicolumn{5}{|c|}{ Unfiltered sample (CDOM plus particles) } & \multicolumn{2}{|c|}{ Particles } \\
\hline & $\begin{array}{r}m_{1} \\
\left(\times 10^{-11}\right)\end{array}$ & $m_{2}$ & $m_{3}$ & $\begin{array}{r}\Phi_{330} \\
\left(\times 10^{-6}\right)\end{array}$ & $\begin{array}{r}\bar{\Phi} \\
\left(\times 10^{-6}\right)\end{array}$ & $\begin{array}{r}m_{1} \\
\left(\times 10^{-11}\right)\end{array}$ & $m_{2}$ & $m_{3}$ & $\begin{array}{r}\Phi_{330} \\
\left(\times 10^{-6}\right)\end{array}$ & $\begin{array}{r}\bar{\Phi} \\
\left(\times 10^{-6}\right)\end{array}$ & $\begin{array}{r}\Phi_{330} \\
\left(\times 10^{-6}\right)\end{array}$ & $\begin{array}{r}\bar{\Phi} \\
\left(\times 10^{-6}\right)\end{array}$ \\
\hline $392-S$ & 0.82 & 5048.7 & 21.3 & 14.3 & 0.91 & 78.7 & 2768.5 & -47.0 & 14.0 & 1.18 & 12.9 & 1.85 \\
\hline 394-S1 & 3.29 & 4371.8 & 7.48 & 13.9 & 0.96 & 7.11 & 3950.0 & -3.17 & 12.6 & 0.92 & 7.67 & 0.76 \\
\hline 394-S2 & 4.02 & 4573.6 & 28.1 & 14.2 & 1.05 & 8.29 & 3806.9 & -13.0 & 13.6 & 0.98 & 7.05 & 0.46 \\
\hline $396-S$ & 6.74 & 4282.3 & 13.1 & 17.8 & 1.31 & 11.5 & 3761.8 & -13.0 & 16.4 & 1.19 & 4.01 & 0.51 \\
\hline $691-S$ & 2.25 & 4410.4 & 0.67 & 14.0 & 0.91 & 2.18 & 4641.0 & 19.6 & 12.7 & 0.88 & 8.69 & 0.81 \\
\hline $692-S$ & 3.64 & 4362.1 & 6.90 & 15.3 & 1.05 & n.d. & n.d. & n.d. & n.d. & n.d. & n.d. & n.d. \\
\hline $693-S$ & 6.77 & 4390.5 & 23.2 & 17.0 & 1.29 & 12.8 & 3803.7 & -6.33 & 16.3 & 1.23 & 13.9 & 1.08 \\
\hline 694-S & 22.2 & 4346.7 & 51.1 & 20.4 & 1.89 & 17.2 & 3872.4 & 1.44 & 20.4 & 1.58 & 20.1 & 1.20 \\
\hline $695-S$ & 12.9 & 4814.8 & 70.3 & 21.7 & 1.97 & 15.8 & 3896.2 & 5.52 & 17.5 & 1.38 & 11.1 & 0.90 \\
\hline 697-S & 13.7 & 4861.1 & 72.5 & 24.1 & 2.19 & 233 & 1900 & -123.4 & 15.0 & 1.14 & 10.0 & 0.81 \\
\hline $170-S$ & 1.34 & 5300.2 & 50.3 & 15.1 & 1.07 & 5.17 & 3604.5 & -41.5 & 13.8 & 0.86 & 11.2 & 0.65 \\
\hline $280-S$ & 0.72 & 4754.1 & 3.93 & 10.9 & 0.67 & 6.98 & 3946.8 & -0.002 & 10.9 & 0.82 & 10.7 & 1.21 \\
\hline 280-D & 0.91 & 6378.6 & 112.5 & 16.5 & 1.30 & n.d. & n.d. & n.d. & n.d. & n.d. & n.d. & n.d. \\
\hline $380-\mathrm{S}$ & 0.47 & 5967.6 & 81.1 & 9.46 & 0.69 & 64.5 & 2277.4 & -83.3 & 6.59 & 0.53 & 3.73 & 0.37 \\
\hline $380-\mathrm{D}$ & 1.00 & 6109.1 & 93.4 & 18.5 & 1.39 & 1.35 & 5425.3 & 63.2 & 13.2 & 0.98 & 7.38 & 0.63 \\
\hline $670-S$ & 1.57 & 4395.3 & -5.80 & 12.1 & 0.76 & 1.64 & 4645.0 & 13.1 & 12.4 & 0.82 & 14.3 & 1.33 \\
\hline $780-\mathrm{S}$ & 1.57 & 4782.9 & 19.8 & 13.7 & 0.91 & 1.66 & 5078.7 & 42.7 & 13.7 & 0.98 & 14.1 & 1.34 \\
\hline 780-D & 0.86 & 4988.9 & 19.0 & 13.8 & 0.87 & 1.57 & 5073.5 & 39.7 & 14.4 & 1.01 & 15.2 & 1.23 \\
\hline $135-\mathrm{D}$ & 0.52 & 6039.2 & 82.9 & 11.7 & 0.84 & 0.59 & 6496.5 & 117.5 & 11.8 & 0.94 & 12.3 & 1.47 \\
\hline $220-S$ & 0.35 & 4566.3 & -19.1 & 8.33 & 0.46 & 0.30 & 4720.0 & -7.50 & 6.91 & 0.40 & 5.49 & 0.33 \\
\hline $220-D$ & 0.57 & 4751.3 & 5.79 & 8.02 & 0.50 & 0.64 & 5004.4 & 24.8 & 8.56 & 0.56 & 12.3 & 1.28 \\
\hline $235-\mathrm{D}$ & 0.63 & 6445.5 & 110.2 & 14.3 & 1.10 & 0.84 & 7057.4 & 155.8 & 17.1 & 1.48 & 25.3 & 3.38 \\
\hline $320-S$ & 0.56 & 4535.7 & -11.9 & 8.70 & 0.51 & 0.35 & 4914.5 & 0.82 & 9.75 & 0.56 & 74.2 & 3.57 \\
\hline $320-\mathrm{D}$ & 0.58 & 6210.1 & 89.2 & 15.8 & 1.14 & 0.80 & 5710.3 & 63.5 & 16.0 & 1.11 & 16.2 & 1.08 \\
\hline $345-\mathrm{D}$ & 0.66 & 5328.9 & 39.4 & 12.1 & 0.80 & 34.8 & 2991.0 & -45.9 & 13.0 & 1.00 & 40.1 & 3.34 \\
\hline $430-S$ & 0.33 & 5719.3 & 48.2 & 12.0 & 0.76 & 0.34 & 6224.4 & 83.5 & 11.7 & 0.82 & 12.4 & 1.34 \\
\hline $430-\mathrm{D}$ & 0.82 & 7489.0 & 182.1 & 18.3 & 1.67 & 0.97 & 6297.7 & 103.0 & 20.2 & 1.54 & 11.4 & 1.41 \\
\hline $460-S$ & 1.00 & 5892.0 & 83.4 & 16.0 & 1.19 & 0.45 & 5520.2 & 39.2 & 14.0 & 0.89 & n.d. & n.d \\
\hline $460-\mathrm{D}$ & 0.81 & 5582.4 & 54.1 & 16.6 & 1.12 & 0.97 & 6071.7 & 91.2 & 17.6 & 1.32 & 19.2 & 1.91 \\
\hline $540-\mathrm{S}$ & 0.35 & 5761.6 & 52.5 & 12.3 & 0.79 & 39.4 & 2880.1 & -50.2 & 11.6 & 0.91 & 8.29 & 1.90 \\
\hline 540-D & 0.88 & 6218.1 & 98.2 & 17.9 & 1.35 & 4.45 & 4713.2 & 34.7 & 18.2 & 1.36 & 31.4 & 1.85 \\
\hline $620-S$ & 1.41 & 4816.2 & 19.5 & 13.6 & 0.90 & 1.45 & 4872.2 & 25.0 & 13.2 & 0.89 & 9.80 & 0.79 \\
\hline $640-S$ & 1.51 & 4770.5 & 18.3 & 13.4 & 0.89 & 1.53 & 4756.6 & 18.6 & 12.9 & 0.86 & 12.4 & 0.83 \\
\hline $760-S$ & 0.86 & 4396.6 & -16.8 & 10.7 & 0.63 & 0.93 & 4442.3 & -12.5 & 10.5 & 0.61 & n.d. & n.d \\
\hline $760-\mathrm{D}$ & 0.65 & 6240.1 & 91.8 & 17.2 & 1.25 & 0.80 & 6505.6 & 112.8 & 19.2 & 1.48 & 27.0 & 2.65 \\
\hline
\end{tabular}

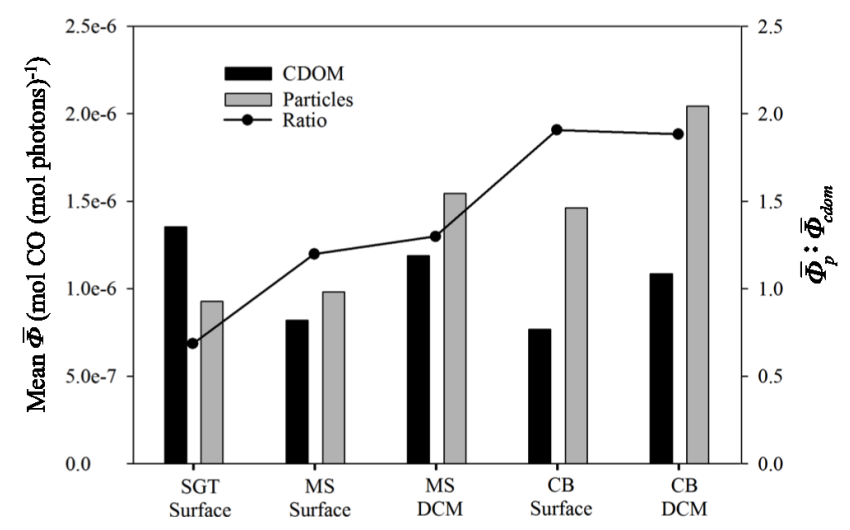

Fig. 3. Comparison of mean $\bar{\Phi}$ of particles and CDOM and the ratio of the two among the three sub-regions. wide range of latitudes decreased $\mathrm{CO}$ photoproduction by 25-36\% (H. Xie and O. C. Zafiriou, unpublished data). In the present study, we reduced the $\mathrm{KCN}$ dose to $4.3 \mu \mathrm{mol} \mathrm{L} \mathrm{L}^{-1}$, which greatly mitigated the $\mathrm{KCN}$ effect on $\mathrm{CO}$ photoproduction while still sufficient to eradicate microbial $\mathrm{CO}$ uptake over the irradiation periods adopted. The $\mathrm{KCN}$ inhibition of $\mathrm{CO}$ production in filtered samples was on average $6.5 \%$ (range: $3.5-16.0 \%, n=20$ ) in the UV domain and negligible in the visible domain. A limited number of tests on unfiltered samples, in which microbial CO consumption was negligible without poisoning, showed a similar suppression of $\mathrm{CO}$ production by $\mathrm{KCN}$. No correction was made for the $\mathrm{KCN}$ effect since it was generally small and not all samples were evaluated. 


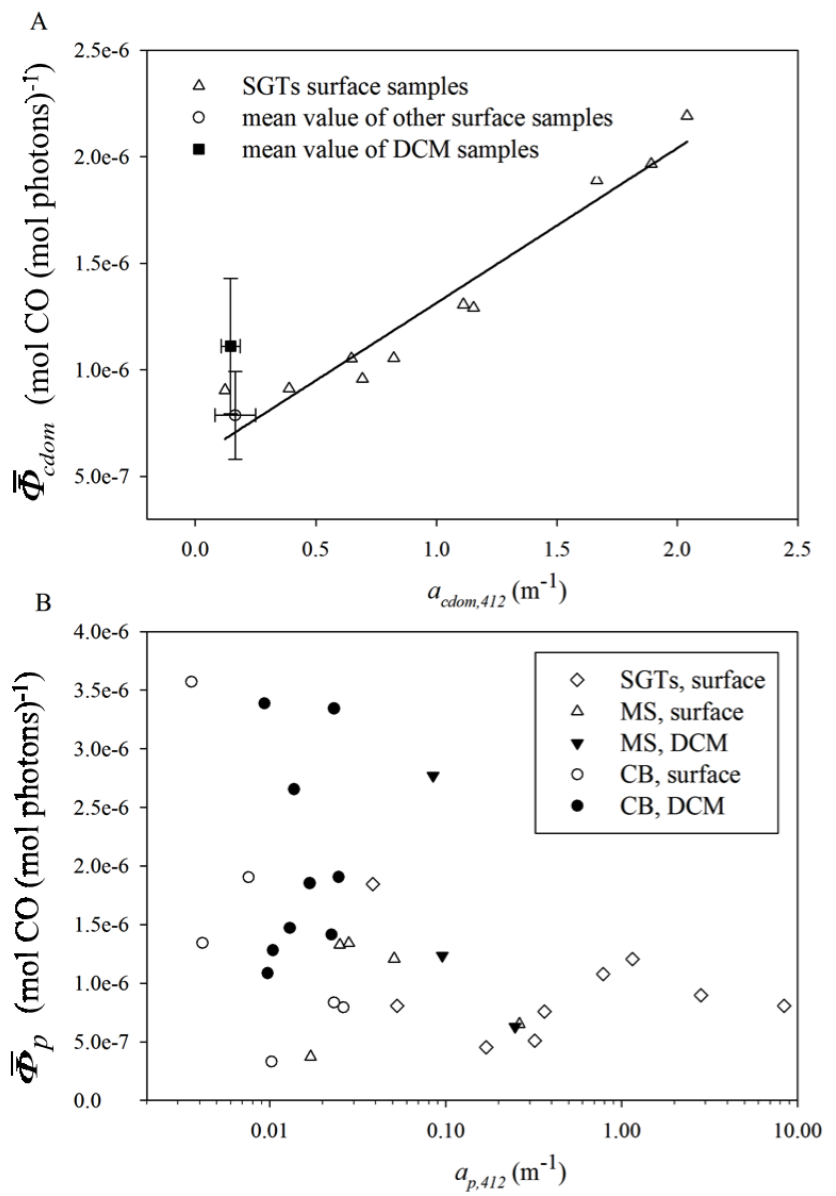

Fig. 4. Relationships between $\bar{\Phi}_{\text {cdom }}$ and $a_{\text {cdom, } 412}$ (A) and between $\bar{\Phi}_{\mathrm{p}}$ and $a_{\mathrm{p}, 412}$ (B). Error bars in (A) are one standard deviation. Solid line in (A) is the best fit to the SGT data and the regression equation is $y=7.27 \times 10^{-7} x+5.87 \times 10^{-7}\left(R^{2}=0.93\right.$, $p<0.0001)$. Note that the $\mathrm{x}$-axis in $(\mathbf{B})$ is on the logarithmic scale.

\subsection{Photoreactivity of CDOM and particles}

The decrease in surface water $\bar{\Phi}_{\text {cdom }}$ from the estuary to open ocean (Fig. 3) suggests that CDOM photoreactivity with respect to CO photoproduction declined seaward. Such a decay of CDOM photoreactivity could be attributed to a progressively increasing proportion of marine CDOM with distance from land and/or structural modifications associated with photobleaching when CDOM was transported across the MS. Marine CDOM is generally less photoreactive than its terrigenous counterpart (Zepp, 2003) and photobleaching reduces CDOM's CO photoproduction efficiency (Zhang et al., 2006). The photoreactivity of particles in surface water, in terms of $\bar{\Phi}_{\mathrm{p}}$, augmented from the estuary to offshore, displaying an inverse tendency to the CDOM photoreactivity (Fig. 3). Hence, marine particles appeared more photoreactive than riverine particulates. Notably, CDOM and particles both exhibited higher photoreactivities at the DCM than at the surface (Fig. 3). The higher CDOM photoreactivity at the
DCM might be linked to the fact that the DCM layer carried CDOM characteristic of the Pacific summer water (Matsuoka et al., 2011, 2012) and that underwater CDOM was shielded from photobleaching. Concerning the particulate phase, fresher cells and/or higher organic contents within the DCM could make the particles there be more photoreactive. The particulate photoreactivity was far below the CDOM photoreactivity in the estuary but the sequence reversed on the MS and in the CB (Fig. 3). This observation of higher particulate photoreactivity for the Arctic shelf and offshore waters is consistent with the results of a previous study using mid-latitude coastal and open waters (Xie and Zafiriou, 2009).

Note that the particulate photoreactivity discussed above refers to the bulk particulate matter without differentiating the organics from inorganics. Doxaran et al. (2012) reported that the mean POC:SPM obtained from the same cruise increased from $2 \%$ in the inner part of the MRE to $11 \%$ in the transitional river plume to $25 \%$ in the open ocean. Based on a POM : POC of 2.6 (Copin-Montégut, 1980; Martin et al., 1993), the parallel POM: SPM was $5.2 \%, 29 \%$ and $65 \%$, demonstrating that minerals were the dominant mass component of SPM in the estuary and river plume. Accordingly, minerals on average contributed $\sim 75 \%$ to $a_{\mathrm{p}, 412}$ along the estuarine transects (Supplement) while this percentage in the CB decreased to $<60 \%$ at the surface and $<19 \%$ at the DCM based on the $a_{\mathrm{phy}, 412}: a_{\mathrm{p}, 412}$ ratios in Table 2 . We estimated that excluding mineral absorption would increase $\bar{\Phi}_{\mathrm{p}}$ by a factor of $\sim 6$ for the estuary but only by $<1.3$ times for the shelf and offshore waters. This correction led to $\bar{\Phi}_{\mathrm{p}}$ for the SGT stations surpassing its CDOM counterpart and being greater than $\bar{\Phi}_{\mathrm{p}}$ for the MS and CB. Hence, terrigenous POM discharged from the Mackenzie River could be more photoreactive with respect to $\mathrm{CO}$ photoproduction as compared to the largely algae-derived marine POM produced in the open Beaufort Sea. However, it should be noted that iron oxides, which often are a primary pigmenting agent for mineralrich terrigenous particles (Stramski et al., 2007; Estapa et al., 2012b), may play a catalytic role in POM photochemistry, similar to the role that dissolved iron plays in CDOM photochemistry (Gao and Zepp, 1998). Hence, the increase in the particulate photoreactivity for the estuarine samples after correcting for the mineral absorption could partly result from the exclusion of the absorption by iron oxides, which might be involved in $\mathrm{CO}$ photoproduction. Clearly, a mechanistic study is needed to elucidate the role of iron and other metals (e.g. $\mathrm{Cu}$ and $\mathrm{Mn}$ ) in particle photochemistry.

Several studies have reported that POM can be photochemically transformed to DOM, including CDOM (Anesio et al., 1999b; Mayer et al., 2009; Pisani et al., 2011). POM-based CO photoproduction could thus arise directly from POM itself or indirectly from POM-derived CDOM. The current study does not aim to distinguish the two pathways. We, however, did monitor the effect of irradiation on CDOM in certain particle-containing samples and found 

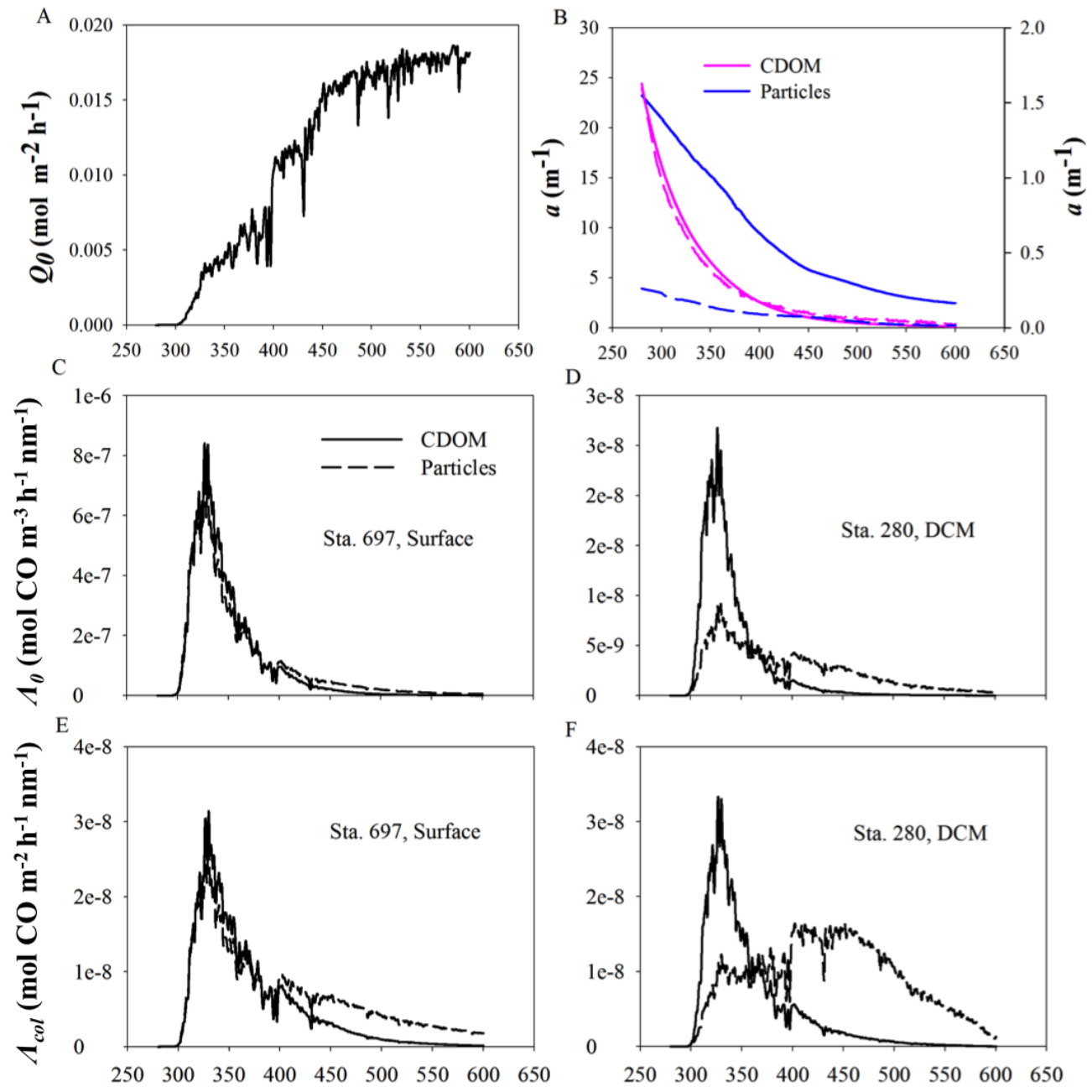

Wavelength (nm)

Fig. 5. Modeled surface spectral solar irradiance (A), $a_{\text {cdom }}$ and $a_{\mathrm{p}}(\mathbf{B})$, surface CO action spectra (C and $\left.\mathbf{D}\right)$ and depth-integrated CO action spectra (E and F). In (B), left y-axis is for Sta. 697 (solid line) and right y-axis for Sta. 280-DCM (dashed line).

no substantial production of new CDOM over the relatively short periods of light exposure adopted in our experiments (mostly $<2$ h) (Fig. S1 in the Supplement). CO photoproduction from newly produced CDOM, if any, should therefore not be the primary process responsible for the particle-driven CO photoproduction observed in this study.

\subsection{Action spectra of $\mathrm{CO}$ photoproduction}

The action spectrum of $\mathrm{CO}$ photoproduction at the sea surface, $\Lambda_{0, \lambda}\left(\mathrm{mol} \mathrm{CO} \mathrm{m}^{-3} \mathrm{~h}^{-1} \mathrm{~nm}^{-1}\right)$, was calculated using Eq. (11),

$\Lambda_{0, \lambda}=Q_{0, \lambda} \times a_{\lambda} \times \Phi_{\lambda}$

where $Q_{0, \lambda}$ is defined in Eq. (10) and $a_{\lambda}$ and $\Phi_{\lambda}$ denote $a_{\text {cdom }, \lambda}$ and $\Phi_{\text {cdom }, \lambda}$ for CDOM and $a_{\mathrm{p}, \lambda}$ and $\Phi_{\mathrm{p}, \lambda}$ for particles (Fig. 5a, b). Both CDOM and particle action spectra were characterized by a non-Gaussian style with the peak response located at $330 \mathrm{~nm}$ and a long tail in the visible (Fig. 5c, d). While the particle action spectra were far below the CDOM's in the UV range $(290-400 \mathrm{~nm})$, the former were conspicuously above the latter across most of the visible section $(>400 \mathrm{~nm})$, leading to a flatter transition from the UV to visible in the particle action spectra. Averaged on action spectra of all surface water samples, UV-B (290-320 nm) contributed $22 \%$ (range: $16-28 \%$ ), UV-A (320-400 nm) 71\% (range: $67-74 \%$ ), and the visible $(400-600 \mathrm{~nm}) 7 \%$ (range: $4-13 \%$ ) to $\Lambda_{0}$ of CDOM integrated over $290-600 \mathrm{~nm}$. The spectral contributions to the wavelength-integrated $\Lambda_{0}$ of particles were: $12 \%$ (range: 4-31\%) from UVB, $60 \%$ (range: $45-70 \%$ ) from UVA and $27 \%$ (range: $5-52 \%$ ) from the visible. The mean percent contribution from the visible displayed little variations across the three sub-regions but was higher for DCM samples $(36 \%)$ than for surface samples $(23 \%)$. The visible 
component in the particle action spectra was on average four times that in the CDOM action spectra.

Depth-integrated action spectra in the photic zone, $\Lambda_{\mathrm{col}, \lambda}$ (mol CO m${ }^{-2} \mathrm{~h}^{-1} \mathrm{~nm}^{-1}$ ), were computed using Eq. (2),

$\Lambda_{\mathrm{col}, \lambda}=Q_{0, \lambda} \times\left(a_{\lambda} / a_{\mathrm{t}, \lambda}\right) \times \Phi_{\lambda}$

Here $a_{\mathrm{t}, \lambda}$ is the total absorption coefficient in the water column, i.e. the sum of $a_{\mathrm{cdom}, \lambda}, a_{\mathrm{p}, \lambda}$, and $a_{\mathrm{w}, \lambda}$ in the euphotic zone. Surface water AQY and absorption values were assumed for the entire euphotic zone, which is a reasonable postulation since the euphotic zone was generally shallower than the surface mixed layer. Like the surface action spectra, the peak-response wavelengths of the water column action spectra also occurred at $330 \mathrm{~nm}$, but their patterns substantially shifted to the visible, particularly for the particle spectra (Fig. 5e, f). Particle action spectra for DCM samples were an exception which lacked the typical, sharp response peak and was characterized by a broad elevation instead (Fig. 5f). This pattern is consistent with the presence of perceptible shoulders in the $\Phi_{\mathrm{p}}$ spectra over the visible band for DCM samples (Fig. 2d, e). Averaged on action spectra of all surface water samples, UV-B, UV-A, and the visible accounted for, respectively, $12 \%$ (range: $8-16 \%$ ), $67 \%$ (range: $62-70 \%$ ), and $21 \%$ (range: $15-30 \%$ ) of CDOM's $\Lambda_{\text {col }}$ integrated from $290-600 \mathrm{~nm}$ and $5 \%$ (range: $1-15 \%$ ), $41 \%$ (range: $26-71 \%$ ), and $55 \%$ (range: $15-73 \%$ ) of particles' $\Lambda_{\text {col }}$. Compared to the surface action spectra, the percent contributions from the visible in the water column action spectra increased for CDOM and especially for particles. The difference in the spectral contributions between the surface and water column action spectra arose from the fact that the UV radiation was more rapidly attenuated than the visible light during their transmission in the water column (Fig. 6a).

To examine the effect of varying spectral light propagation on the depth dependence of $\mathrm{CO}$ photoproduction in the water column, we modeled the vertical distribution of spectral solar photon fluxes using Eq. (13),

$Q_{z, \lambda}=Q_{0, \lambda} \times \exp \left(-k_{\mathrm{d}, \lambda} \times z\right)$

where $Q_{z, \lambda}$ is the spectral photon flux at depth $z$ (m) and $k_{\mathrm{d}, \lambda}$ the diffuse attenuation coefficient $\left(\mathrm{m}^{-1}\right.$ ) (Doxaran et al., 2012). The action spectrum at depth $z, \Lambda_{z, \lambda}$ $\left(\mathrm{mol} \mathrm{CO} \mathrm{m} \mathrm{m}^{-3} \mathrm{~h}^{-1} \mathrm{~nm}^{-1}\right)$, is given by

$\Lambda_{z, \lambda}=Q_{z, \lambda} \times a_{\lambda} \times \Phi_{\lambda}$

$Q_{z, \lambda}$ and $\Lambda_{z, \lambda}$ for the UV-B, UV-A and visible bands were calculated by integration over the relevant wavelength ranges. Clearly, the visible light and visible-driven $\mathrm{CO}$ production penetrated much deeper than their UV-B and UV-A counterparts (Fig. 6a-c). Consequently, the relative contribution of the visible to full-spectrum (290-600 nm) CO production increased with depth for both CDOM and particles (Fig. 6d). Concerning the full spectrum-integrated $\Lambda_{z}$, the ratio of particles to $\mathrm{CDOM}$ rose from $4 \%$ at the surface to $38 \%$ at the base of the euphotic zone (Fig. 6r), due evidently to the dominance of $\Phi_{\mathrm{p}, \lambda}$ over $\Phi_{\mathrm{cdom}, \lambda}$ at the visible wavelengths (Fig. 2).

\subsection{Modeling CO photoproduction}

$\mathrm{CO}$ photoproduction rates from CDOM and particles were modeled at each station for the sampling season of $\mathrm{Au}-$ gust 2009. The production rates at the surface $(0 \mathrm{~m})$, $P_{0}\left(\mu \mathrm{mol} \mathrm{CO} \mathrm{m} \mathrm{m}^{-3} \mathrm{~d}^{-1}\right)$, and in the euphotic zone (depthintegrated), $P_{\text {col }}\left(\mu \mathrm{mol} \mathrm{CO} \mathrm{m}{ }^{-2} \mathrm{~d}^{-1}\right)$, were calculated using Eqs. (15) and (16), respectively,

$$
\begin{aligned}
& P_{0}=\int_{290}^{600} Q_{0-, \lambda} \times a_{\lambda} \times \Phi_{\lambda} \times \mathrm{d} \lambda \\
& P_{\text {col }}=\int_{290}^{600} Q_{\mathrm{d} 0-, \lambda} \times\left(a_{\lambda} / a_{\mathrm{t}, \lambda}\right) \times \Phi_{\lambda} \times d \lambda
\end{aligned}
$$

$P_{0}, P_{\mathrm{col}}, a_{\lambda}$, and $\Phi_{\lambda}$ denote $P_{\mathrm{cdom}, 0}$ and $P_{\mathrm{p}, 0}, P_{\mathrm{cdom}, \mathrm{col}}$ and $P_{\mathrm{p}, \text { col }}, a_{\mathrm{cdom}, \lambda}$ and $a_{\mathrm{p}, \lambda}$, and $\Phi_{\mathrm{cdom}, \lambda}$ and $\Phi_{\mathrm{p}, \lambda}$ for CDOM and particles, respectively. $Q_{0-, \lambda}$ is the scalar photon flux just beneath the surface (mol photons $\mathrm{m}^{-2} \mathrm{~d}^{-1} \mathrm{~nm}^{-1}$ ) and $a_{\mathrm{t}, \lambda}$ the sum of $a_{\mathrm{cdom}, \lambda}, a_{\mathrm{p}, \lambda}$, and $a_{\mathrm{w}, \lambda}$ in the water column. $Q_{0-, \lambda}$ was estimated as 1.3 times the downwelling photon flux $\left(Q_{\mathrm{d} 0-, \lambda}\right)$ (Gordon, 1989). $Q_{\mathrm{d} 0-, \lambda}$ was simulated using the Santa Barbara DISORT Atmospheric Radiative Transfer (SBDART) software developed by Ricchiazzi et al. (1998) at $3 \mathrm{~h}$ intervals, taking into account of the cloud cover and ozone conditions. Major factors influencing solar incident irradiance, such as cloud fraction, cloud optical thickness, and ozone abundance, were obtained from the International Satellite Cloud Climatology Project (ISCCP, http://isccp.giss.nasa.gov/products/browsed2.html). Eqs. (15) and (16) employed surface water $a_{\lambda}$ and $\Phi_{\lambda}$ and assumed vertical uniformity of the two parameters in the euphotic zone. Areal CO photoproduction in ice-free water, $\sum P_{\text {col }}$, was calculated separately for the MRE, MS, and CB by multiplying the mean $P_{\text {col }}$ by the open water area for each sub-region. Demarcation of the three sub-regions is described in Fig. 1. Daily sea ice cover data were provided by the US National Snow and Ice Data Center (NSIDC, http://nsidc.org/).

Both $P_{\text {cdom, } 0}$ and $P_{\mathrm{p}, 0}$ reached maxima, $214 \mu \mathrm{mol} \mathrm{CO} \mathrm{m} \mathrm{m}^{-3} \mathrm{~d}^{-1}$ and $212 \mu \mathrm{mol} \mathrm{CO} \mathrm{m} \mathrm{m}^{-3} \mathrm{~d}^{-1}$, at the most nearshore Sta. 697, in line with the highest $a_{\text {cdom }}$ and $a_{\mathrm{p}}$ observed at this locality (see Sect. 3.1). The minimum $P_{\text {cdom, } 0}\left(2.0 \mu \mathrm{mol} \mathrm{CO} \mathrm{m} \mathrm{m}^{-3} \mathrm{~d}^{-1}\right)$ and $P_{\mathrm{p}, 0}$ $\left(0.09 \mu \mathrm{mol} \mathrm{CO} \mathrm{m} \mathrm{m}^{-3} \mathrm{~d}^{-1}\right)$ occurred, respectively, at the offshore Sta. 430 and Sta. 220 having low CDOM and particle abundances. $P_{\mathrm{p}, 0}: P_{\text {cdom, } 0}$ was highest at Sta. $697(0.99)$ and lowest $(0.02)$ at Sta. 220, conforming to the parallel high (4.1) and low (0.10) $a_{\mathrm{p}}: a_{\mathrm{cdom}}$. The maximum $P_{\text {cdom, col }}$ 


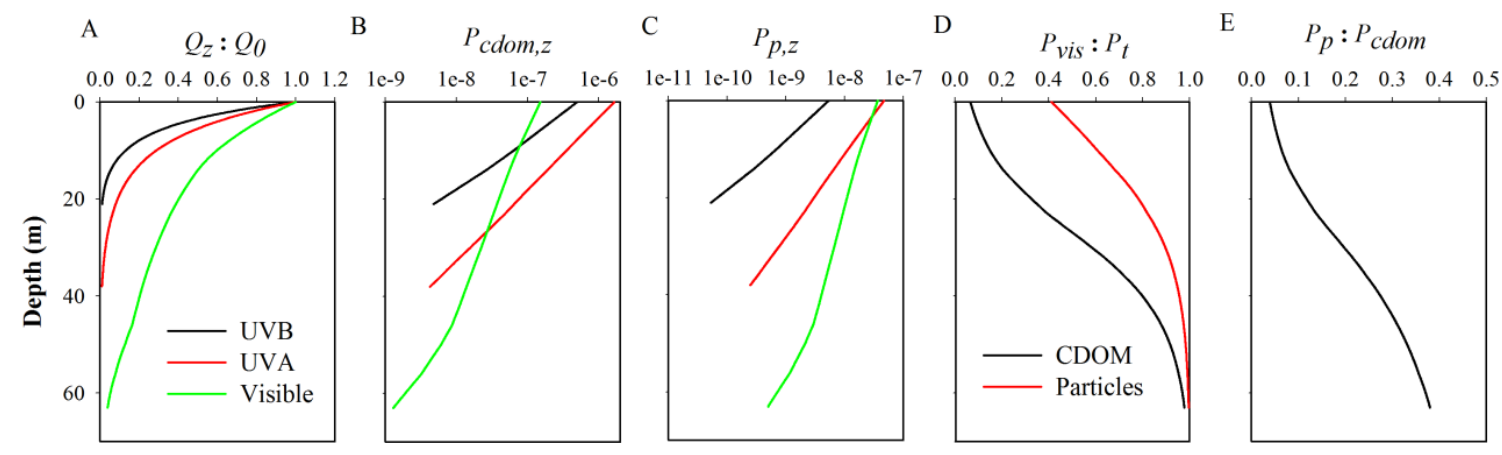

Fig. 6. Modeled vertical profiles of normalized solar irradiance (A), CO photoproduction rate $\left(\mathrm{molCO} \mathrm{m} \mathrm{m}^{-3} \mathrm{~h}^{-1}\right)$ from $\mathrm{CDOM}(\mathbf{B})$ and particles (C), the contribution of visible to full-spectrum CO photoproduction (D), and the ratio of full-spectrum particle-based to CDOMbased CO photoproduction (E) at Sta. 430.

$\left(18.8 \mu \mathrm{mol} \mathrm{CO} \mathrm{m}^{-2} \mathrm{~d}^{-1}\right)$ and $P_{\mathrm{p}, \mathrm{col}}\left(10.2 \mu \mathrm{mol} \mathrm{CO} \mathrm{m}^{-2} \mathrm{~d}^{-1}\right)$ were found, respectively, at Sta. 170 in the upwelling zone and at Sta. 697 in the innermost area of the estuary while the minimum $P_{\text {cdom, col }}\left(6.9 \mu \mathrm{mol} \mathrm{CO} \mathrm{m}{ }^{-2} \mathrm{~d}^{-1}\right)$ and $P_{\mathrm{p}, \mathrm{col}}$ $\left(0.3 \mu \mathrm{mol} \mathrm{CO} \mathrm{m}{ }^{-2} \mathrm{~d}^{-1}\right)$ were present, respectively, at Sta. 320 and Sta. 220 in offshore waters, respectively. Like $P_{\mathrm{p}, 0}: P_{\text {cdom }, 0}, P_{\mathrm{p}, \text { col }}: P_{\text {cdom, col was also highest at Sta. } 697}$ (1.2) and lowest at Sta. $220(0.02)$. Note that $P_{\mathrm{p}, \mathrm{col}}$ surpassed $P_{\text {cdom, col }}$ at Sta. 697, which had the highest $a_{\mathrm{p}, 412}: a_{\text {cdom, } 412}$ (4.1). This result suggests that the significance of particle photochemistry can overtake that of CDOM photochemistry in highly turbid waters, consistent with the finding of Estapa et al. (2012a) for DOC photoproduction.

Table 4 summarizes the means of modeled CO production rates and other related parameters for each sub-region. $P_{\text {cdom }, 0}, P_{\mathrm{p}, 0}$, and $P_{\mathrm{p}, 0}: P_{\text {cdom, } 0}$ all decreased from the estuary to the shelf to the basin, which evolved in the same manner as $a_{\text {cdom }}, a_{\mathrm{p}}$, and $a_{\mathrm{p}}: a_{\text {cdom }}$, respectively (Table 2 ). $P_{\text {cdom, col }}$ exhibited little regional variations while $P_{\mathrm{p}, \text { col }}$ declined by $54 \%$ from the estuary to the shelf and by $57 \%$ from the shelf to the basin. $P_{\mathrm{p}, \mathrm{col}}: P_{\mathrm{cdom}, \mathrm{col}}$ thus decreased seaward by roughly the same extents as those for $P_{\mathrm{p}, \mathrm{col}}$. Because of widening open water area seaward, $\sum P_{\text {cdom, col }}$ augmented from the estuary to the shelf to the basin, contrary to the $P_{\text {cdom, col }}$ tendency. The combination of relatively high particle abundance and large open water area rendered the MS to possess the highest $\sum P_{\mathrm{p}, \text { col }}$. The total CO photoproduction in the entire study area in August 2009 amounted to $67 \times 10^{6}$ moles, of which $14 \%$ was produced by POM photodegradation.

Note that the estimates in Table 4 were based on CO AQY data determined at $4{ }^{\circ} \mathrm{C}$ while surface water temperature in the sampling area spanned from $-0.8^{\circ} \mathrm{C}$ to $10.3^{\circ} \mathrm{C}$ (Table 1) and decreased seaward (Sect. 3.1). Using water samples from the St. Lawrence estuarine system, Zhang et al. (2006) observed a $30-70 \%$ (depending on salinity) increase in CO photoproduction from CDOM with a $20^{\circ} \mathrm{C}$ increase in temperature. Although little is known about the temperature de-
Table 4. Arithmetic means ( \pm s.d.) of $P_{0}, P_{\mathrm{col}}, \sum P_{\mathrm{col}}$, and $a_{\mathrm{p}, 412}: a_{\text {cdom, } 412}$ in August 2009 based on individual stations within each sub-region. Keys for MS and CB are the same as those in Table 1.

\begin{tabular}{|c|c|c|c|}
\hline & MRE* & MS & $\mathrm{CB}$ \\
\hline$a_{\mathrm{p}, 412}: a_{\text {cdom }, 412}$ & 0.94 & 0.39 & 0.09 \\
\hline \multicolumn{4}{|c|}{$P_{0}\left(\mu \mathrm{mol} \mathrm{m}{ }^{-3} \mathrm{~d}^{-1}\right)$} \\
\hline$P_{\text {cdom }, 0}$ & $90 \pm 72$ & $13 \pm 7$ & $6.7 \pm 5$ \\
\hline$P_{\mathrm{p}, 0}$ & $42 \pm 69$ & $1.8 \pm 2$ & $0.4 \pm 0.2$ \\
\hline$P_{\mathrm{p}, 0}: P_{\text {cdom }, 0}$ & 0.47 & 0.14 & 0.05 \\
\hline \multicolumn{4}{|c|}{$P_{\mathrm{col}}\left(\mu \mathrm{mol} \mathrm{m}{ }^{-2} \mathrm{~d}^{-1}\right)$} \\
\hline$P_{\text {cdom, col }}$ & $14 \pm 3$ & $13 \pm 4$ & $12 \pm 3$ \\
\hline$P_{\mathrm{p}, \mathrm{col}}$ & $5.0 \pm 3$ & $2.3 \pm 2$ & $1.0 \pm 0.6$ \\
\hline$P_{\mathrm{p}, \mathrm{col}}: P_{\mathrm{cdom}, \mathrm{col}}$ & 0.37 & 0.18 & 0.08 \\
\hline \multicolumn{4}{|c|}{$\sum P_{\mathrm{col}}\left(10^{3} \mathrm{~mol} \mathrm{COd}^{-1}\right)$} \\
\hline$\sum P_{\text {cdom, col }}$ & $302 \pm 62$ & $681 \pm 188$ & $866 \pm 244$ \\
\hline$\sum P_{\mathrm{p}, \mathrm{col}}$ & $111 \pm 72$ & $120 \pm 87$ & $73 \pm 44$ \\
\hline Total & $413 \pm 57$ & $800 \pm 272$ & $930 \pm 301$ \\
\hline \multicolumn{3}{|c|}{ Total CO photoproduction in August $\left(10^{6} \mathrm{~mol} \mathrm{CO}\right)$} & $67 \pm 20$ \\
\hline
\end{tabular}

* MRE $=$ Mackenzie River estuary.

pendence of particulate $\mathrm{CO}$ photoproduction, particle photoprocesses (e.g. DOC photoproduction) appear to be more strongly affected by temperature than many dissolved-phase photoreactions (Mayer et al., 2006; Espapa et al., 2012a). Therefore, the effect of temperature variation on $\mathrm{CO}$ photoproduction in the present study could be significant for both CDOM and particles. Here we tentatively assessed this effect based on the results of Zhang et al. (2006), assuming roughly equal extents of temperature dependence for the two pathways. The temperature correction increased $\sum P_{\text {cdom, col }}$ and $\sum P_{\mathrm{p}, \text { col }}$ by $22 \%$ in the estuary and $7 \%$ on the shelf but deceased them by $2 \%$ in the basin. The total CO 


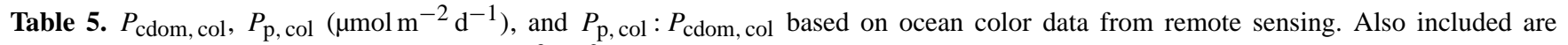
$a_{\mathrm{p}}: a_{\text {cdom }}$ at $412 \mathrm{~nm}$ and open water area $\left(\times 10^{3} \mathrm{~km}^{2}\right.$ ) (Xie et al., 2012). Keys for MRE, MS and CB are the same as those in Table 4.

\begin{tabular}{|c|c|c|c|c|c|c|c|c|}
\hline & & Apr & May & Jun & Jul & Aug & Sep & Annual \\
\hline \multirow{5}{*}{$\mathrm{MRE}+\mathrm{MS}$} & $a_{\mathrm{p}}: a_{\mathrm{cdom}}$ & 0.74 & 0.76 & 0.67 & 0.65 & 0.33 & 0.42 & 0.50 \\
\hline & Area & 2.2 & 12.3 & 43.1 & 63.5 & 74.5 & 74.4 & 74.5 \\
\hline & $P_{\text {cdom, col }}$ & 6.6 & 10.4 & 15.8 & 16.7 & 12.2 & 6.6 & 9.6 \\
\hline & $P_{\mathrm{p}, \mathrm{col}}$ & 2.9 & 4.5 & 6.5 & 4.5 & 2.4 & 1.2 & 2.6 \\
\hline & $P_{\mathrm{p}, \mathrm{col}}: P_{\text {cdom, col }}$ & 0.44 & 0.43 & 0.41 & 0.27 & 0.20 & 0.18 & 0.27 \\
\hline \multirow{5}{*}{$\mathrm{CB}$} & $a_{\mathrm{p}}: a_{\mathrm{cdom}}$ & 0.76 & 0.49 & 0.42 & 0.31 & 0.28 & 0.27 & 0.30 \\
\hline & Area & 0.25 & 12.5 & 43.9 & 58.9 & 74.0 & 79.0 & 79.0 \\
\hline & $P_{\text {cdom, col }}$ & 6.9 & 10.9 & 16.5 & 18.2 & 10.2 & 5.3 & 9.8 \\
\hline & $P_{\mathrm{p}, \mathrm{col}}$ & 3.3 & 2.9 & 3.6 & 2.7 & 1.5 & 0.7 & 1.6 \\
\hline & $P_{\mathrm{p}, \mathrm{col}}: P_{\mathrm{cdom}, \mathrm{col}}$ & 0.47 & 0.27 & 0.22 & 0.15 & 0.14 & 0.13 & 0.17 \\
\hline
\end{tabular}

production in August 2009 increased from $67 \times 10^{6}$ moles to $71 \times 10^{6}$ moles.

It should also be pointed out that the particulate to CDOM $\mathrm{CO}$ photoproduction ratios reported in Table 4 were arithmetic averages of these ratios for individual stations within each sub-region. The individual CO production ratios were based on the corresponding individual $a_{\mathrm{p}}: a_{\text {cdom }}$ measured. Because of limited spatial coverage by the sampling stations, snapshots of $a_{\mathrm{p}}: a_{\text {cdom }}$ might not be representative of the entire sub-region in question. We therefore also evaluated $P_{\mathrm{p}, \text { col }}$ and $P_{\mathrm{cdom}, \mathrm{col}}$ using monthly averaged remote sensing-derived $a_{\mathrm{t}}$ (Bélanger, 2006) and $a_{\mathrm{cdom}}: a_{\mathrm{t}}$ (Bélanger et al., 2008), from which $a_{\mathrm{p}}$ and $a_{\text {cdom }}$ (hence $a_{\mathrm{p}}: a_{\text {cdom }}$ ) can be calculated since $a_{\mathrm{t}}=a_{\mathrm{p}}+a_{\mathrm{cdom}}+a_{\mathrm{w}}$ and $a_{\mathrm{w}}$ is known (Buiteveld et al., 1994; Pope and Fry, 1997). The $a_{\mathrm{p}}, a_{\mathrm{cdom}}$ and $a_{\mathrm{p}}: a_{\text {cdom }}$ in the present study were obtained from the remote sensing-based $a_{\mathrm{cdom}}$ and $a_{\mathrm{cdom}}: a_{\mathrm{t}}$ published by Xie et al. (2012, their Table 3$)$. The $P_{\mathrm{p}, \mathrm{col}}, P_{\mathrm{cdom}, \mathrm{col}}$, and $P_{\mathrm{p}, \mathrm{col}}: P_{\mathrm{cdom}, \mathrm{col}}$ derived from ocean color imaging are shown in Table 5. In addition to the sampling month (August), estimates were also made for other months, assuming seasonally constant $\Phi_{\mathrm{p}}: \Phi_{\text {cdom }}$ (Table 5). The satellitederived $P_{\mathrm{p}, \text { col }}: P_{\text {cdom, col }}$ in August was similar to the individual stations-based ratio for the MS (including MRE), but the former was nearly twice the latter for the CB due to the much higher $a_{\mathrm{p}}: a_{\text {cdom }}$ ratio from remote sensing. $P_{\mathrm{p}, \text { col }}: P_{\text {cdom, col }}$ generally decreased from April (MS: 0.44; CB: 0.47) to September (MS: 0.18; CB: 0.13) and followed a similar pattern for $a_{\mathrm{p}}: a_{\text {cdom }}$, underscoring the importance of the POM versus CDOM absorption seasonality in controlling the POM- versus CDOM-based CO photoproduction dynamics. The open water area-normalized annual $P_{\mathrm{p}, \mathrm{col}}: P_{\mathrm{cdom}, \mathrm{col}}$ reached 0.27 on the MS and 0.17 in the $\mathrm{CB}$. These values are within the range reported by Xie and Zafiriou (2009) for mid-latitude coastal and open ocean waters.

\section{Summary}

AQY spectra of CO photoproduction from CDOM and particles were determined using water samples from the Mackenzie estuary, shelf, and Canada Basin. Bulk particulate matterbased CO AQY increased from the estuary and shelf to the basin, opposite to the trend of CDOM-based CO AQY. Samples from the deep chlorophyll maximum layer displayed higher CO AQY for both particles and CDOM than did surface water samples. CO AQY of bulk particulate matter in shelf and offshore waters exceeded that of CDOM, but the reverse held for estuarine water. Excluding the contribution of minerals to the absorption coefficient of the bulk particles, POM-based CO AQY in estuarine water could surpass its CDOM counterpart and the POM-based CO AQY in offshore waters. While CDOM's CO AQY generally increased linearly with the CDOM's absorption coefficient, particulate matter's CO AQY did not show consistent relationships with its optical properties. The spectral shape of particle-based CO AQY was flatter than that of CDOM-based CO AQY in the visible wavelengths, leading to a continuously increasing proportion of $\mathrm{CO}$ produced from particles with depth in the water column. Although depth-integrated CO photoproduction from CDOM was primarily driven by the UV radiation, the visible domain contributed roughly as much as the UV to CO photoproduction from particles. AQY-based coupled optical-photochemical modeling indicates that $\mathrm{CO}$ photoproduction from particles in the study area was equivalent to $13-47 \%$ of that from CDOM. Future studies are needed to elucidate the roles of metals (e.g. iron oxides) and chlorophylls in POM-based CO photoproduction.

\section{Supplementary material related to this article is available online at: http://www.biogeosciences.net/10/ 3731/2013/bg-10-3731-2013-supplement.pdf.}




\section{Appendix A}

Table A1. List of symbols.

\begin{tabular}{|c|c|c|}
\hline Symbol & Meaning & Unit \\
\hline$a$ & absorption coefficient & $\mathrm{m}^{-1}$ \\
\hline$a_{\mathrm{cdom}}$ & absorption coefficient of CDOM & $\mathrm{m}^{-1}$ \\
\hline$a_{\text {nap }}$ & absorption coefficient of non-algal particles & $\mathrm{m}^{-1}$ \\
\hline$a_{\mathrm{p}}$ & absorption coefficient of particles & $\mathrm{m}^{-1}$ \\
\hline$a_{\text {phy }}$ & absorption coefficient of phytoplanktonic pigments & $\mathrm{m}^{-1}$ \\
\hline$a_{\mathrm{t}}$ & absorption coefficient of the sum of $a_{\mathrm{cdom}}, a_{\mathrm{p}}$, and $a_{\mathrm{w}}$ & $\mathrm{m}^{-1}$ \\
\hline$a_{\mathrm{W}}$ & absorption coefficient of pure water & $m^{-1}$ \\
\hline$A$ & clearance area of filters for retaining particles & $\mathrm{m}^{2}$ \\
\hline $\mathrm{bb}_{m}$ & particle backscattering coefficient & $\mathrm{m}^{-1}$ \\
\hline$\beta$ & path length amplification factor & unitless \\
\hline$k_{\mathrm{d}}$ & diffuse attenuation coefficient & $m^{-1}$ \\
\hline$\lambda$ & wavelength & $\mathrm{nm}$ \\
\hline$L$ & light path length of irradiation cells & $\mathrm{m}$ \\
\hline OD & optical density & unitless \\
\hline OD $_{\text {blank }}$ & optical density of blank GF/F filter & unitless \\
\hline $\mathrm{OD}_{\text {cdom }}$ & optical density of CDOM & unitless \\
\hline $\mathrm{OD}_{f}$ & optical density of particles & unitless \\
\hline$P_{0}$ & CO photoproduction rate at the surface & $\mu \mathrm{mol} \mathrm{CO} \mathrm{m}{ }^{-3} \mathrm{~d}^{-1}$ \\
\hline$P_{\text {cdom, } 0}$ & CO photoproduction rate at the surface from CDOM & $\mu \mathrm{mol} \mathrm{CO} \mathrm{m}{ }^{-3} \mathrm{~d}^{-1}$ \\
\hline$P_{\mathrm{p}, 0}$ & $\mathrm{CO}$ photoproduction rate at the surface from particles & $\mu \mathrm{mol} \mathrm{CO} \mathrm{m}{ }^{-3} \mathrm{~d}^{-1}$ \\
\hline$P_{\mathrm{col}}$ & depth-integrated CO photoproduction rate in the euphotic zone & $\mu \mathrm{mol} \mathrm{CO} \mathrm{m}{ }^{-2} \mathrm{~d}^{-1}$ \\
\hline$P_{\text {cdom, col }}$ & $\begin{array}{l}\text { depth-integrated CO photoproduction rate in the euphotic zone } \\
\text { from CDOM }\end{array}$ & $\mu \mathrm{mol} \mathrm{CO} \mathrm{m}{ }^{-2} \mathrm{~d}^{-1}$ \\
\hline$P_{\mathrm{p}, \mathrm{col}}$ & $\begin{array}{l}\text { depth-integrated } \mathrm{CO} \text { photoproduction rate in the euphotic zone } \\
\text { from particles }\end{array}$ & $\mu \mathrm{mol} \mathrm{CO} \mathrm{m}{ }^{-2} \mathrm{~d}^{-1}$ \\
\hline$\sum P_{\mathrm{col}}$ & area-integrated CO photoproduction in the euphotic zone & $\operatorname{molCO} \mathrm{m}^{-2} \mathrm{~d}^{-1}$ \\
\hline$\sum P_{\text {cdom, col }}$ & $\begin{array}{l}\text { area-integrated CO photoproduction in the euphotic zone } \\
\text { from CDOM }\end{array}$ & $\operatorname{molCO~m}{ }^{-2} \mathrm{~d}^{-1}$ \\
\hline$\sum P_{\mathrm{p}, \mathrm{col}}$ & $\begin{array}{l}\text { area-integrated } \mathrm{CO} \text { photoproduction in the euphotic zone } \\
\text { from particles }\end{array}$ & $\operatorname{molCO} \mathrm{m}^{-2} \mathrm{~d}^{-1}$ \\
\hline$\Phi$ & CO apparent quantum yield (AQY) & $\operatorname{mol~CO}(\text { mol photons })^{-1}$ \\
\hline$\Phi_{\text {cdom }}$ & AQY from CDOM & $\operatorname{mol~CO}{\text { (mol photons })^{-1}}^{-1}$ \\
\hline$\Phi_{\mathrm{p}}$ & AQY from particles & mol CO (mol photons) $)^{-1}$ \\
\hline$\Phi_{\mathrm{t}}$ & AQY from CDOM plus particles & $\operatorname{molCO}(\text { mol photons })^{-1}$ \\
\hline $\bar{\Phi}$ & solar irradiance spectrum-weighted mean $\Phi(290-600 \mathrm{~nm})$ & $\operatorname{mol~CO}(\text { mol photons })^{-1}$ \\
\hline $\bar{\Phi}_{\text {cdom }}$ & $\begin{array}{l}\text { solar irradiance spectrum-weighted mean } \Phi(290-600 \mathrm{~nm}) \\
\text { for CDOM }\end{array}$ & $\operatorname{mol~CO}(\text { mol photons })^{-1}$ \\
\hline $\bar{\Phi}_{\mathrm{p}}$ & $\begin{array}{l}\text { solar irradiance spectrum-weighted mean } \Phi(290-600 \mathrm{~nm}) \\
\text { for particles }\end{array}$ & mol CO (mol photons $)^{-1}$ \\
\hline $\bar{\Phi}_{\mathrm{t}}$ & $\begin{array}{l}\text { solar irradiance spectrum-weighted mean } \Phi(290-600 \mathrm{~nm}) \\
\text { for CDOM plus particles }\end{array}$ & mol CO (mol photons $)^{-1}$ \\
\hline$Q$ & photon flux just below the frontal quartz window & mol photons $\mathrm{m}^{-2} \mathrm{~s}^{-1} \mathrm{~nm}^{-1}$ \\
\hline$Q_{\mathrm{a}}$ & photons absorbed by CDOM, particles, or both combined & mol photons $\mathrm{m}^{-2} \mathrm{~s}^{-1} \mathrm{~nm}^{-1}$ \\
\hline$Q_{0}$ & modeled surface solar photon fluxes & mol photons $\mathrm{m}^{-2} \mathrm{~h}^{-1} \mathrm{~nm}^{-1}$ \\
\hline$Q_{0-}$ & scalar photon flux just beneath the sea surface & mol photons $\mathrm{m}^{-2} \mathrm{~d}^{-1} \mathrm{~nm}^{-1}$ \\
\hline$Q_{\mathrm{d} 0-}$ & downwelling photon flux just beneath the sea surface & mol photons $\mathrm{m}^{-2} \mathrm{~d}^{-1} \mathrm{~nm}^{-1}$ \\
\hline$Q_{z}$ & photon flux at depth $z(\mathrm{~m})$ & mol photons $\mathrm{m}^{-2} \mathrm{~d}^{-1} \mathrm{~nm}^{-1}$ \\
\hline$\widehat{S}$ & cross-section of the irradiation cells & $\mathrm{m}^{-2}$ \\
\hline$V$ & filtered volume of seawater through $\mathrm{GF} / \mathrm{F}$ filters & $\mathrm{m}^{3}$ \\
\hline$\Lambda_{0}$ & surface $\mathrm{CO}$ action spectrum & $\operatorname{molCO} \mathrm{m}^{-3} \mathrm{~h}^{-1} \mathrm{~nm}^{-1}$ \\
\hline$\Lambda_{\mathrm{col}}$ & depth-integrated $\mathrm{CO}$ action spectrum & $\operatorname{mol~CO~m}{ }^{-2} \mathrm{~h}^{-1} \mathrm{~nm}^{-1}$ \\
\hline$\Lambda_{z}$ & $\mathrm{CO}$ action spectrum at depth $\mathrm{z}$ & $\operatorname{molCO} \mathrm{m}^{-3} \mathrm{~h}^{-1} \mathrm{~nm}^{-1}$ \\
\hline
\end{tabular}


Table A2. List of abbreviations.

\begin{tabular}{ll}
\hline Abbreviation & Meaning \\
\hline AQY & apparent quantum yield \\
CB & Canada Basin \\
CDOM & chromophoric dissolved organic matter \\
Chl $a$ & chlorophyll $a$ \\
DCM & deep chlorophyll maximum \\
MRE & Mackenzie River estuary \\
MS & Mackenzie Shelf \\
POM & particulate organic matter \\
SGT-E & salinity gradient transect-east channel \\
SGT-W & salinity gradient transect-west channel \\
SPM & suspended particulate matter \\
UVA & Ultraviolet-A (320-400 nm) \\
UVB & Ultraviolet-B (290-320 nm) \\
\hline
\end{tabular}

Acknowledgements. We thank D. Doxaran and J. Ehn for providing the POC, SPM, and backscattering data. We are grateful to M. Babin, the chief scientist of the CCGS Amundsen cruise and the principal investigator of the Malina program. Reviewers' and editor's suggestions notably improved the manuscript. This study was supported by grants from NSERC (Natural Sciences and Engineering Research Council) and conducted as part of the Malina Scientific Program funded by ANR (Agence nationale de la recherche), INSU-CNRS (Institut national des sciences de l'univers - Centre national de la recherche scientifique), CNES (Centre national d'études spatiales) and ESA (European Space Agency). GS received graduate scholarships from ISMER (Institut des sciences de la mer de Rimouski) and FRQNT (Fonds de recherche du Québec - Nature et technologies).

Edited by: W. Miller

\section{References}

Anesio, A. M., Tranvik, L. J., and Granéli, W.: Production of inorganic carbon from aquatic macrophytes by solar radiation, Ecology, 80, 1852-1859, 1999a.

Anesio, A. M., Denward, C. M. T., Tranvik, L. J., and Granéli, W.: Decreased bacterial growth on vascular plant detritus due to photochemical modification, Aquat. Microb. Ecol., 17, 159-165, 1999b.

Babin, M., Stramski, D., Ferrari, G. M., Claustre, H., Bricaud, A., Obolensky, G., and Hoepffner, N.: Variations in the light absorption coefficients of phytoplankton, nonalgal particles, and dissolved organic matter in coastal waters around Europe, J. Geophy. Res., 108, 3211, doi:10.1029/2001JC000882, 2003.

Bélanger, S.: Response of light-related carbon fluxes in the Arctic Ocean to climate change: Quantification and monitoring of dissolved organic matter photo-oxidation in the Beaufort Sea using satellite remote sensing, Ph.D. thesis, Université Pierre et Marie Curie (UPMC- Paris XI), Paris, France, 2006.

Bélanger, S., Xie, H., Krotkov, N., Larouche, P., Vincent, W. F., and Babin, M: Photomineralization of terrigenous dissolved organic matter in Arctic coastal waters from 1979 to 2003: Interan- nual variability and implications of climate change, Global Biogeochem. Cy., 20, GB4005, doi:10.1029/2006GB002708, 2006.

Bélanger, S., Babin, M., and Larouche, P.: An empirical ocean color algorithm for estimating the contribution of chromophoric dissolved organic matter to total light absorption in optically complex waters, J. Geophys. Res., 113, C04027, doi:10.1029/2007JC004436, 2008.

Benner, R. and Biddanda, B.: Photochemical transformations of surface and deep marine dissolved organic matter: Effects on bacterial growth, Limnol. Oceanogr., 43, 1373-1378, 1998.

Benner, R., Louchouarn, P., and Amon, R. M. W.: Terrigenous dissolved organic matter in the Arctic Ocean and its transport to surface and deep waters of the North Atlantic, Global Biogeochem Cy., 19, GB2025, doi:10.1029/2004GB002398, 2005.

Brimblecombe, P.: The global sulfur cycle, in: Biogeochemistry: Treatise on geochemistry, edited by: Schlesinger, W. H., Elsevier Ltd., 645-682, 2003.

Buiteveld, H., Hakvoort, J. M. H., and Donze, M.: The optical properties of pure water, in: SPIE proceeding on ocean optics XII. The Society of Photo-Optical Instrumentation Engineers, edited by: Jaffe, J. S., 174-183, 1994.

Bushaw, K. L., Zepp, R. G., Tarr, M. A., Schulz-Jander, D., Bourboniere, R. A., Hodson, R. E., Miller, W. L., Bronk, D. A., and Moran, M. A.: Photochemical release of biologically labile nitrogen from aquatic dissolved organic matter, Nature, 381, 404 407, 1996.

Conrad, R., Seiler, W., Bunse, G., and Giehl, H.: Carbon monoxide in seawater (Atlantic Ocean), J. Geophy. Res., 87, 8839-8852, 1982.

Copin-Montégut, G.: Matières en suspension dans les eaux de mer: répartition composition chimique, origine et evolution, Thèse d'état. Université Pierre et Marie Curie Paris IV, 173 pp., 1980.

Dittmar, T. and Kattner, G.: The biogeochemistry of the river and shelf ecosystem of the Arctic Ocean: a review, Mar. Chem., 83, 103-120, 2003.

Doxaran, D., Ehn, J., Bélanger, S., Matsuoka, A., Hooker, S., and Babin, M.: Optical characterisation of suspended particles in the Mackenzie River plume (Canadian Arctic Ocean) and implications for ocean colour remote sensing, Biogeosciences, 9, 32133229, doi:10.5194/bg-9-3213-2012, 2012.

Estapa, M. L. and Mayer, L. M.: Photooxidation of particulate organic matter, carbon/oxygen stoichiometry, and related photoreactions, Mar. Chem. 122, 138-147, 2010.

Estapa, M. L., Mayer, L. M., and Boss, E.: Rate and apparent quantum yield of photodissolution of sedimentary organic matter, Limnol. Oceanogr. 57, 1743-1756, 2012a.

Estapa, M. L., Boss, E., Mayer, L. M., and Roesler, C. S.: Role of iron and organic carbon in mass-specific light absorption by particulate matter from Louisiana coastal waters, Limnol. Oceanogr., 57, 97-112, 2012b.

Fichot, C. G. and Miller, W. L.: An approach to quantify depthresolved marine photochemical fluxes using remote sensing: Application to carbon monoxide $(\mathrm{CO})$ photoproduction, Remote Sens. Environ., 114, 1363-1377, 2010.

Fioletov, V. E., Kimlin, M. G., Krotkov, N., McArthur, L. J. B., Kerr, J. B., Wardle, D. I., Herman, J. R., Meltzer, R., Mathews, T. W., and Kaurola, J.: UV index climatology over the United States and Canada from ground-based and satellite estimates, J. Geophys. Res., 109, D22308, doi:10.1029/2004JD004820, 2004. 
Flato, G. M., Boer, G. J., Lee, W. G., McFarlane, N. A., Ramsden, D., Reader, M. C., and Weaver, A. J.: The Canadian Centre for climate modeling and analysis global coupled model and its climate, Clim. Dynam., 16, 451-467, 2000.

Forest, A., Sampei, M., Hattori, H., Makabe, R., Sasaki, H., Fukuchi, M., Wassmann, P., and Fortier, L.: Particulate organic carbon fluxes on the slope of the Mackenzie Shelf (Beaufort Sea): Physical and biological forcing of shelf-basin exchange, J. Marine Syst., 68, 39-54, 2007.

Gao, H. and Zepp, R. G.: Factors influencing photoreactions of dissolved organic matter in a coastal river of the southeastern United States, Environ. Sci. Technol, 32, 2940-2946, 1998.

Goñi, M. A., Yunker, M. B., Macdonald, R. W., and Eglinton, T. I.: The supply and preservation of ancient and modern components of organic carbon in the Canadian Beaufort Shelf of the Arctic Ocean, Mar. Chem., 93, 53-73, 2005.

Gordon, H. R.: Can the Lambert-Beer law be applied to the diffuse attenuation coefficient of ocean water, Limnol. Oceanogr., 34, 1389-1409, 1989.

Gueymard, C. A.: Parameterized transmittance model for direct beam and circumsolar spectral irradiance, Sol. Energy, 71, 325346, 2001.

Hansell, D. A., Kadko, D., and Bates, N. R.: Degradation of terrigenous dissolved organic carbon in the western Arctic Ocean, Science, 304, 858-861, 2004.

Holm-Hansen, O., Lorenzen, C. J., Holmes, R. W., and Strickland, J. D.: Fluorometric determination of chlorophyll, J. Cons. Int. Explor. Mer., 30, 3-15, 1965.

Hu, C., Muller-Karger, F. E., and Zepp, R. G.: Absorbance, absorption coefficient, and apparent quantum yield: A comment on common ambiguity in the use of these optical concepts, Limnol. Oceanogr., 47, 1261-1267, 2002.

Johannessen, S. C. and Miller, W. L.: Quantum yield for the photochemical production of dissolved inorganic carbon in seawater, Mar. Chem., 76, 271-283, 2001.

Kettle, A. J.: Diurnal cycling of carbon onoxide (CO) in the upper ocean near Bermuda, Ocean Model., 8, 337-367, 2005.

Kieber, R. J., Whitehead, R. F., and Skrabal, S.A.: Photochemical production of dissolved organic carbon from resuspended sediment, Limnol. Oceanogr., 51, 2187-2195, 2006.

King, G. M. and Weber, C. F.: Distribution, diversity and ecology of aerobic CO-oxidizing bacteria, Nat. Rev. Microbiol., 5, 107-118, 2007.

Kirk, J. T. O.: Spectral adsorption properties of natural waters: contribution of the soluble and particulate fractions to light absorption in some inland waters of south-eastern Australia, Aust. J. Mar. Fresh. Res., 31, 287-296, 1980.

Leymarie, E., Doxaran, D., and Babin, M.: Uncertainties associated to measurements of inherent optical properties in natural waters, Appl. Opt., 49, 5415-5436, 2010.

Macdonald, R. W., Carmack, E. C., McLaughlin, F. A., Falkner, K. K., and Swift, J. H.: Connections among ice, runoff and atmospheric forcing in the Beaufort Gyre, Geophy. Res. Lett., 26, 2223-2226, 1999.

Magen, C., Chaillou, G., Crowe, S. A., Mucci, A., Sundby, B., Gao, A., Makabe, R., and Sasaki, H.: Origin and fate of particulate organic matter in the southern Beaufort Sea - Amundsen Gulf region, Canadian Arctic, Estuar. Coast. Shelf S., 86, 31-41, 2010.
Martin, J. M., Guana, D. M., Elbaz-Poulichet, F., Thomas, A. J., and Gordeev, V. V.: Preliminary assessment of the distributions of some trace elements ( $\mathrm{As}, \mathrm{Cd}, \mathrm{Cu}, \mathrm{Fe}, \mathrm{Ni}, \mathrm{Pb}$ and $\mathrm{Zn}$ ) in a pristine aquatic environment: the Lena River estuary (Russia), Mar. Chem., 43, 185-199, 1993.

Matsuoka, A., Hill, V., Huot, Y., Bricaud, A., and Babin, M.: Seasonal variability in the light absorption properties of western Arctic waters: parameterization of the individual components of absorption for ocean color applications, J. Geophys. Res., 116, C02007, doi:10.1029/2009JC005594, 2011.

Matsuoka, A., Bricaud, A., Benner, R., Para, J., Sempéré, R., Prieur, L., Bélanger, S., and Babin, M.: Tracing the transport of colored dissolved organic matter in water masses of the Southern Beaufort Sea: relationship with hydrographic characteristics, Biogeosciences, 9, 925-940, doi:10.5194/bg-9-925-2012, 2012.

Mayer, L. M., Schick, L. L., Skorko, K., and Boss, E.: Photodissolution of particulate organic matter from sediments, Limnol. Oceanogr., 51, 1064-1071, 2006.

Mayer, L. M., Schick, L. L., Hardy, K. R., and Margaret, L. E.: Photodissolution and other photochemical changes upon irradiation of algal detritus, Limnol. Oceanogr., 54, 1688-1698, 2009.

McLaughlin, F. A., Carmack, E. C., Macdonald, R. W., and Bishop, J. K. B.: Physical and geochemical properties across the Atlantic/Pacific water mass front in the southern Canadian Basin, J. Geophy. Res., 101, 1183-1197, 1996.

Miller, G. C. and Zepp, R. G: Effects of suspended sediments on photolysis rates of dissolved pollutants, Water Res., 13, 453-459, 1979.

Miller, W. L. and Zepp, R. G.: Photochemical production of dissolved inorganic carbon from terrestrial organic matter: Significance to the oceanic organic carbon cycle, Geophy. Res. Lett., 22, 417-420, 1995.

Miller, W. L., Moran, M. A., Sheldon, W. M., Zepp, R. G., and Opsahl, S.: Determination of apparent quantum yield spectra from the formation of biologically labile photoproducts, Limnol. Oceanogr., 47, 343-352, 2002.

Mopper, K. and Kieber, D. J.: Photochemistry and the cycling of carbon, sulfur, nitrogen and phosphorus, in: Biogeochemistry of marine dissolved organic matter, edited by: Hansell, D. A. and Carlson, C. A., Academic Press, San Diego, USA, 456-508, 2002.

Moran, M. A. and Miller, W. L.: Resourceful heterotrophs make the most of light in the coastal ocean, Nat. Rev. Microbiol., 5, 1-10, 2007.

Nelson, J. R.: Rates and possible mechanism of light-dependent degradation of pigments in detritus derived from phytoplankton, J. Mar. Res., 51, 155-179, 1993.

Opsahl, S., Benner, R., and Amon, R. M. W.: Major flux of terrigenous dissolved organic matter through the Arctic Ocean, Limnol. Oceanogr., 44, 2017-2023, 1999.

Osburn, C. L., Retamal, L., and Vincent, W. F.: Photoreactivity of chromophoric dissolved organic matter transported by the Mackenzie River to the Beaufort Sea, Mar. Chem., 115, 10-20, 2009.

Parsons, T. R., Maita, Y., and Lalli, C. M.: A manual of chemical and biological methods for seawater analysis, Pergamon, New York, 1984.

Pisani, O., Yamashita, Y., and Jaffé, R.: Photo-dissolution of flocculent, detrital material in aquatic environments: Contributions 
to the dissolved organic matter pool, Water Res., 45, 3836-3844, 2011.

Pope, R. M. and Fry, E. S.: Absorption spectrum (380-700 nm) of pure water. 2. Integrating cavity measurements, Appl. Opt., 36, 8710-8723, 1997.

Ricchiazzi, P., Yang, S., and Gautier, C.: A Practical Tool for PlaneParallel Radiative Transfer in the Earth's Atmosphere, available at http://arm.mrcsb.com/sbdart/html/sbdart-intro.html, 1998.

Riggsbee, J. A., Orr, C. H., Leech, D. M., Doyle, M. W., and Wetzel, R. G.: Suspended sediments in river ecosystems: photochemical sources of dissolved organic carbon and adsorptive removal of dissolved iron, J. Geophys. Res., 113, G03019, doi:10.1029/2007JG000654, 2008.

Rontani, J.-F.: Visible light-dependent degradation of lipidic phytoplanktonic components during senescence: a review, Phytochemistry, 58, 187-202, 2001.

Röttgers, R. and Gehnke, S.: Measurement of light absorption by aquatic particles: improvement of the quantitative filter technique by use of an integrating sphere approach, Appl. Opt., 51, 13361351, 2012.

Shank, G. C., Evans, A., Yamashita, Y., and Jaffé, R.: Solar radiation - enhanced dissolution of particulate organic matter from coastal marine sediments, Limnol. Oceanogr., 56, 577-588, 2011.

Stedmon, C. A., Amon, R. M. W., Rinehart, A. J., and Walker, S. A.: The supply and characteristics of colored dissolved organic matter (CDOM) in the Arctic Ocean: Pan Arctic trends and differences, Mar. Chem., 124, 108-118, 2011.

SooHoo, J. B. and Kiefer, D. A.: Vertical distribution of phaeopigments-II. Rates of production and kinetics of photooxidation, Deep Sea Res. Pt. A, 29, 1553-1563, 1982.

Stramski, D., Babin, M., and Woźniak, S.: Variations in the optical properties of terrigenous mineral-rich particulate matter suspended in seawater, Limnol. Oceanogr., 52, 2418-2433, 2007.

Stroeve, J., Serreze, M., Drobot, S., Gearheard, S., Holland, M., Maslanik, J., Meier, W., and Scambos, T.: Arctic sea ice extent plummets in 2007, Eos Trans., 89, 13-14, doi:10.1029/2008EO020001, 2008.

Stubbins, A., Uher, G., Kitidis, V., Law, C. S., Upstill-Goddard, R. C., and Woodward, E. M. S.: The open-ocean source of atmospheric carbon monoxide, Deep-Sea Res. II, 53, 1685-1694, 2006.

Stubbins, A., Law, C. S., Uher, G., and Upstill-Goddard, R. C.: Carbon monoxide apparent quantum yields and photoproduction in the Tyne estuary, Biogeosciences, 8, 703-713, doi:10.5194/bg-8703-2011, 2011.

Tarr, M. A., Miller, W. L., and Zepp, R. G.: Direct carbon monoxide photoproduction from plant matter, J. Geophy. Res., 100, 1140311413, 1995.
Tremblay, J.-É., Simpson, K., Martin, J., Miller, L., Gratton, Y., Barber, D., and Price, N. M.: Vertical stability and the annual dynamics of nutrients and chlorophyll fluorescence in the coastal, southeast Beaufort Sea, J. Geophys. Res., 113, C079S90, doi:10.1029/2007JC004547, 2008.

Williams, W. J. and Carmack, E. C.: Combined effect of windforcing and isobaths divergence on upwelling at Cape Bathurst, Beaufort Sea, J. Mar. Res., 66, 645-663, 2008.

White, E. M., Kieber, D. J., Sherrard, J., Miller, W. L., and Mopper, K.: Carbon dioxide and carbon monoxide photoproduction quantum yields in the Delaware Estuary, Mar. Chem., 118, 11$21,2010$.

Xie, H. and Zafiriou, O. C.: Evidence for significant photochemical production of carbon monoxide by particles in coastal and oligotrophic marine waters, Geophy. Res. Lett, 36, L23606, doi:10.1029/2009GL041158, 2009.

Xie, H., Andrews, S. S., Martin, W. R., Miller, J., Ziolkowski, L., Taylor, C. D., and Zafiriou, O. C.: Walidated methods for sampling and headspace analysis of carbon monoxide in seawater, Mar. Chem., 77, 93-108, 2002.

Xie, H., Bélanger, S., Demers, S., Vincent, W. F., and Papakytiakou, T. N.: Photobiogeochemical cycling of carbon monoxide in the southeastern Beaufort Sea in spring and autumn, Limnol. Oceanogr., 54, 234-249, 2009.

Xie, H., Bélanger, S., Song, G., Benner, R., Taalba, A., Blais, M., Tremblay, J.-É., and Babin, M.: Photoproduction of ammonium in the southeastern Beaufort Sea and its biogeochemical implications, Biogeosciences, 9, 3047-3061, doi:10.5194/bg-9-30472012, 2012.

Zafiriou, O. C.: Sunburnt organic matter: Biogeochemistry of lightaltered substrates, Limnol. Oceanogr. Bulletin, 11, 69-74, 2002.

Zafiriou, O. C., Andrews, S. S., and Wang, W.: Concordant estimates of oceanic carbon monoxide source and sink process in the Pacific yield a balanced global "blue-water" CO budget, Global Biogeochem. Cy., 17, 1015, doi:10.1029/2001GB001638, 2003.

Zepp, R. G.: Solar UVR and aquatic carbon, nitrogen, sulfur and metals cycles, in: UV effects in aquatic organisms and ecosystems, edited by: Helbling, E. W. and Zagarese, H., The royal society of chemistry, Cambridge, UK, 137-183, 2003.

Zhang, Y., Xie, H., and Chen, G.: Factors affecting the efficiency of carbon monoxide photoproduction in the St. Lawrence Estuarine system (Canada), Environ. Sci. Technol., 40, 7771-7777, 2006.

Ziolkowski, L. A. and Miller W. L.: Variability of the apparent quantum efficiency of CO photoproduction in the Gulf of Maine and Northwest Atlantic, Mar. Chem., 105, 258-270, 2007. 